AMERICAN ACADEMY OF ARTS \& SCIENCES

\title{
AMERICA'S ANGUAGES
}

Investing in Language

Education for the 21st Century 



\section{AMERICA'S LANGUAGES Investing in Language Education for the 21st Century}

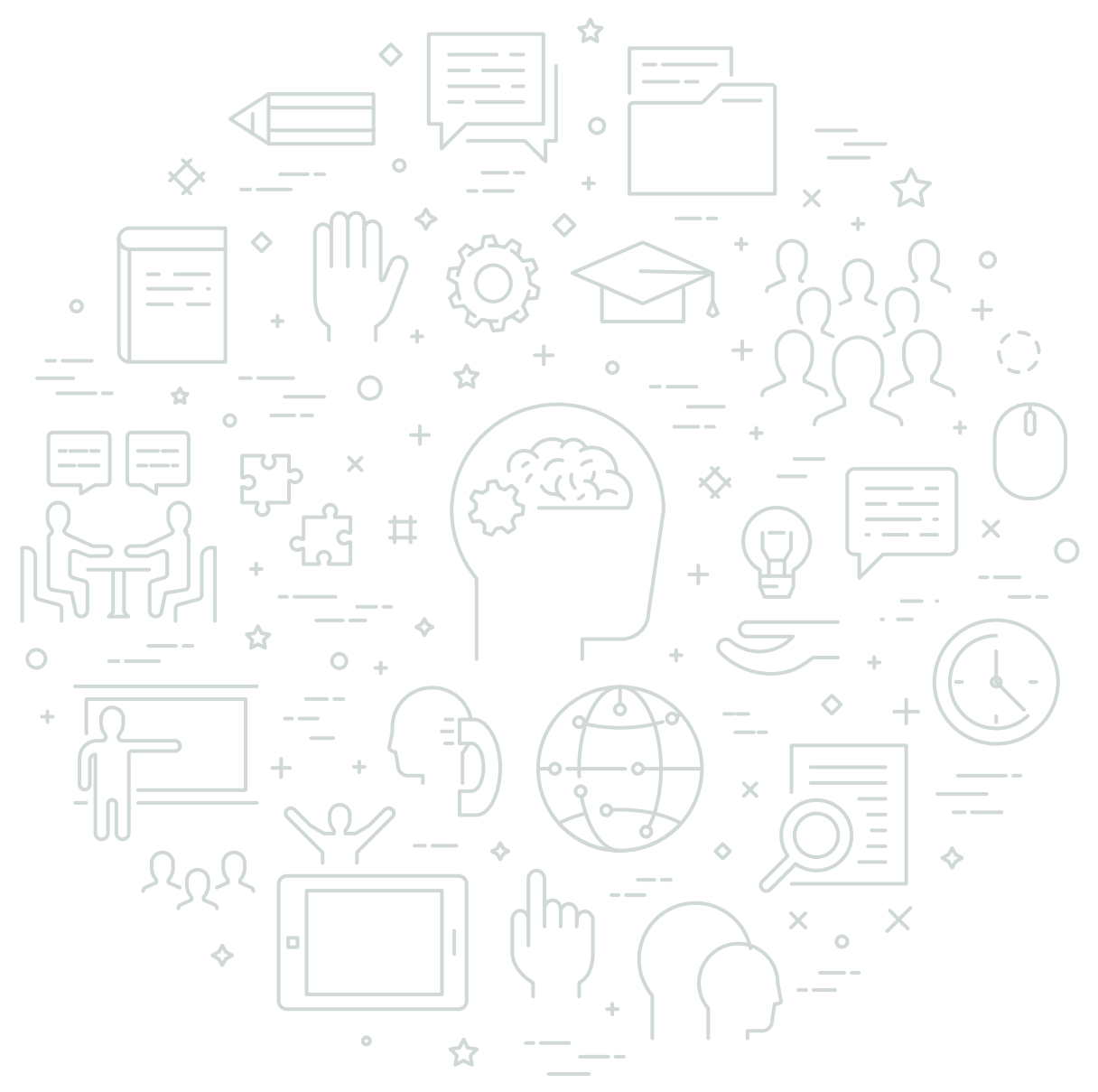


(C) 2017 by the American Academy of Arts \& Sciences

All rights reserved.

ISBN: 0-87724-112-O

This publication is available online at https://www.amacad.org/language.

The views expressed in this publication are those held by the contributors and are not necessarily those of the Officers and Members of the American Academy of Arts \& Sciences.

Please direct inquiries to:

American Academy of Arts \& Sciences

136 Irving Street

Cambridge, MA 02138-1996

Telephone: 617-576-5002

Fax: 617-576-5050

Email: language@amacad.org

Web: www.amacad.org 


\section{Contents}

Acknowledgments

Preface

vii

Executive Summary

Key Findings of this Report

viii

Key Recommendations of the Commission

Introduction

1

Section 1: Building Educational Capacity

8

Section 2: Involving Local Communities, Businesses, and Philanthropies

Section 3: Developing Heritage Languages and Revitalizing Native American Languages

22

Section 4: Encouraging International Study and Cultural Immersion

Conclusion

Endnotes

32

Congressional Letters

39

Commissioner Biographies

43 



\section{Acknowledgments}

America's Languages: Investing in Language Education for the 21st Century is the American Academy's response to a bipartisan request from four members of the United States Senate and four members of the House of Representatives to examine the following questions:

How does language learning influence economic growth, cultural diplomacy, the productivity of future generations, and the fulfillment of all Americans? What actions should the nation take to ensure excellence in all languages as well as international education and research, including how we may more effectively use current resources to advance language learning?

This request followed, and was inspired by, the important work of the Academy's Commission on the Humanities and Social Sciences and its 2013 report, The Heart of the Matter: The Humanities and Social Sciences for a Vibrant, Competitive, and Secure Nation. The Heart of the Matter included a strong endorsement for the development of intercultural skills, including language learning. The bipartisan request asked the Academy to expand upon and elaborate that recommendation.

The Academy created its Commission on Language Learning in 2015 to gather data, collect testimony, and discuss opportunities for improving the nation's capacity in non-English languages. In late 2016, the Commission, in collaboration with the Academy's Humanities Indicators project, published The State of Languages in the U.S.: A Statistical Portrait, which offers a quantitative analysis of our language capacity, focusing on the U.S. education system. America's Languages draws from this data to offer a series of concrete recommendations for schools, two- and four-year colleges, universities, community organizations, businesses, government agencies, philanthropists, students, and parents-all of whom have a role to play in preparing citizens to thrive in the twenty-first century. As the Commission writes in this report's introduction: "It is critical that we work together at this moment in history, when there is so much to gain by participating in a multilingual world, and so much to lose if we remain stubbornly monolingual."

The Academy is grateful to the members of Congress who requested this study: Senators Tammy Baldwin (D-Wisconsin), Orrin G. Hatch (R-Utah), Mark Kirk (R-Illinois), and Brian Schatz (D-Hawaii); and Representatives Rush Holt (D-New Jersey), Leonard Lance (R-New Jersey), David E. Price (D-North Carolina), and Don Young (R-Alaska).

We offer special thanks to Commission chair, Paul LeClerc, director of Columbia Global Centers-Paris and former president of the New York Public Library, whose active engagement and steady leadership made this work possible. Thanks as well goes to all the Commission members, whose expertise, creativity, and dedication are evident in the pages that follow. (See page 43 for the biographies of all Commission members.) 
The Commission sought advice from a wide range of experts over the past two years. We are grateful to all of them for their insights and their suggestions for improving this report, including Douglas Massey (Princeton University), Catherine E. Snow (Harvard University), Philip J. Deloria (University of Michigan), Helen Hardacre (Harvard University), Kenji Hakuta (Stanford University), William P. Rivers (Joint National Committee for Languages, National Council for Languages and International Studies), Richard D. Brecht (American Councils for International Education), Eva Caldera (National Endowment for the Humanities), Stephen Kidd (National Humanities Alliance), Esther Mackintosh (Federation of State Humanities Councils), Maureen McLaughlin (U.S. Department of Education), Mohamed Abdel-Kader (U.S. Department of Education), Carol J. Erting (Gallaudet University), Meriwynn Mansori (VIF International Education), Gilles Bousquet (University of Wisconsin-Madison), Anandini Yoganathan (British Academy), Nelke van Dussen-Scholl (Yale University), Fernando Rubio (The University of Utah), Johanna Watzinger-Tharp (The University of Utah), and Jane Hacking (The University of Utah).

The Commission is grateful to have received briefing essays from several leading scholars: Terrence Wiley, Beatriz Arias, Jennifer Renn, and Shereen Bhalla from the Center for Applied Linguistics; William P. Rivers from the JNCL-NCLIS; Richard D. Brecht from the American Councils for International Education; Judith F. Kroll and Paola E. Dussias from the Pennsylvania State University; and Gail H. McGinn from the U.S. Department of Defense, retired. These essays are now available at www.amacad.org/language.

Thanks as well to the members of the Academy's Board of Directors, Council, and Trust for their leadership, advice, and support for this project, and to the Academy staff who ably served this Commission and prepared this report: John Tessitore, Julian Kronick, Esha Senchaudhuri, Robert Townsend, Carolyn Fuqua, Phyllis Bendell, Heather Mawhiney, Peter Walton, and Scott Raymond.

Finally, the Academy gratefully acknowledges the Andrew W. Mellon Foundation and the Henry Luce Foundation for supporting the Commission on Language Learning, and the Andrew W. Mellon Foundation and the National Endowment for the Humanities for supporting the Humanities Indicators.

We hope you will find this report informative and useful, and that you will find ways to implement its recommendations in your own communities. We also look forward to hearing your thoughts about this report and about other ways to support language education in the United States.

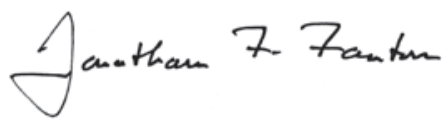

Jonathan F. Fanton

President

American Academy of Arts and Sciences 


\section{Preface}

In the spring of 1781 , members of the American Academy of Arts and Sciences met in the County Courthouse in Boston to discuss the areas of study that should "principally engage the attention of the Academy" in the years ahead.

The Academy had been founded only one year earlier by a group of statesmen and business leaders —including John Adams, Samuel Adams, John Hancock, and James Bowdoin-who were, as the American Revolution was nearing its conclusion, planning to create a new country. Their goal for the Academy was "to cultivate every art and science which may tend to advance the interest, honor, dignity, and happiness of a free, independent, and virtuous people."

In setting an agenda for the Academy, its members were also establishing an intellectual program for the new nation. They focused on practical inquiries that would have real consequences for scientific discovery, for the expansion of commerce, and for the encouragement of a productive civic life-studies in mathematics and astronomy, vegetation and minerology, medicine and history. Among the first ten topics they identified as key to both the Academy's and the nation's future was the study of language.

The Academy's founders understood that the study of language in the United States was a complex and varied endeavor. They supported inquiries into "the rationale, genius and idiom of the English language," but they also encouraged examinations of Native American languages and of linguistics more generally. They believed that an appreciation for the plurality of languages would improve communication domestically and internationally, and help the new nation understand its place in a changing world. ${ }^{1}$

Two hundred and thirty-five years later, in 2014, a bipartisan group of members of Congress asked the Academy to take up the question of language again. Responding to a world that seems infinitely more complex than at the nation's founding-driven by a global flow of people, capital, technologies, and ideas that has brought the multilingual world closer than ever before-four members of the United States Senate and four members of the House of Representatives signed two letters requesting that the Academy examine the nation's current capacity in languages and recommend actions "to ensure excellence in all languages as well as international education and research.” (See page 39 for the Congressional Letters.)

This report, authored by the Academy's Commission on Language Learning, is a response to that request. 


\section{Executive Summary}

According to the U.S. Census Bureau, more than sixty-five million U.S. residents speak a language other than English at home-a number that has been growing decade by decade since the 1970s. Nevertheless, that number represents only 20.7 percent of the total population, and only a fraction of this cohort speaks, reads, and comprehends a second language well enough to use it in their everyday lives. ${ }^{2}$ The vast majority of American citizens remain monolingual.

While English continues to be the lingua franca for world trade and diplomacy, there is an emerging consensus among leaders in business and politics, teachers, scientists, and community members that proficiency in English is not sufficient to meet the nation's needs in a shrinking world, nor the needs of individual citizens who interact with other peoples and cultures more than at any other time in human history.

In this report, the Commission on Language Learning recommends a national strategy to improve access to as many languages as possible for people of every region, ethnicity, and socioeconomic background-that is, to value language education as a persistent national need similar to education in math or English, and to ensure that a useful level of proficiency is within every student's reach. As children prove especially receptive to language education-they spend much of their time in educational settings and can develop language skills gradually throughout their lives-the Commission believes that instruction should begin as early in life as possible. Its primary goal, therefore, is for every school in the nation to offer meaningful instruction in world languages as part of their standard curricula.

As a corollary, the Commission urges two- and four-year colleges and universities to continue to offer beginning and advanced language instruction to all students, and to reverse recent programmatic cuts wherever possible. It also applauds recent efforts to create new undergraduate language requirements on two- and four-year campuses.

\section{KEY FINDINGS OF THIS REPORT}

The ability to understand, speak, read, and write in world languages, in addition to English, is critical to success in business, research, and international relations in the twenty-first century.

The United States needs more people to speak languages other than English in order to provide social and legal services for a changing population.
The study of a second language has been linked to improved learning outcomes in other subjects, enhanced cognitive ability, and the development of empathy and effective interpretive skills. The use of a second language has been linked to a delay in certain manifestations of aging.

The United States lags behind most nations of the world, including European nations and China, in the percentage of its citizens who have some knowledge of a second language. 
One of the biggest obstacles to improved language learning is a national shortage of qualified teachers. Forty-four states and Washington, D.C., report that they cannot find enough qualified teachers to meet current needs, but every school district in the nation responds to the teacher shortage in its own way (by cutting classes, by combining classes, by contracting before- or after-school enrichment programs, to name a few). We need better information about these districtlevel responses to attach a specific number to the national teacher shortage, and encourage any study that advances our knowledge of its size and scope.
Technological innovations will play an ever more significant role in language learning, as a motivating factor for a new generation of students, as a means for providing educational opportunities to more students across the nation, and as an aid and reference for people in their everyday lives.

- Native American languages are distinct in political status and history, and are the object of school- and community-based reclamation and retention efforts aligned with the Native American Languages Act of 1990 (NALA). ${ }^{3}$

\section{KEY RECOMMENDATIONS OF THE COMMISSION}

The report focuses on five capacity-building goals and includes many more specific recommendations:

1. Increase the number of language teachers at all levels of education so that every child in every state has the opportunity to learn a language in addition to English.

- Encourage the coordination of state credentialing systems so that qualified teachers can find work in regions where there are significant shortages.

Attract talented and enthusiastic language teachers through federal loan forgiveness programs.

Develop and distribute online and digital technologies, as well as blended learning models, particularly in communities with a short supply of language teachers.
- Provide new opportunities for advanced study in languages in higher education -for future language teachers as well as scholars in other fields-through a recommitment to language instruction, blended learning programs, and the development of new regional consortia allowing two- and four-year colleges and universities to pool learning resources. 
2. Supplement language instruction across the education system through public-private partnerships among schools, government, philanthropies, businesses, and local community members.

Draw on local and regional resources by working with heritage language communities and other local experts to create in-school and after-school instructional programming.
Maintain support for state humanities councils and other organizations that create vital language and cultural resources for local communities.

3. Support heritage languages already spoken in the United States, and help these languages persist from one generation to the next.

Encourage heritage language speakers to pursue further instruction in their heritage languages.

Provide more language learning opportunities for heritage speakers in classroom or school settings.
Expand efforts to create college and university curricula designed specifically for heritage speakers and to offer course credit for proficiency in a heritage language.

4. Provide targeted support and programming for Native American languages as defined in the Native American Languages Act.

Increase support for Native American languages being used as primary languages of education, and for the development of curricula and education materials for such programs.
Provide opportunities for Native Americans and others to study Native American languages in English-based schools with appropriate curricula and materials.

5. Promote opportunities for students to learn languages in other countries by experiencing other cultures and immersing themselves in multilingual environments.

Encourage high schools and universities to facilitate learning abroad opportunities for students.

Increase the number of international internships sponsored by businesses and NGOs.
Restructure federal financial aid to help low-income undergraduates experience study abroad during the summer as well as the academic year. 


\section{Introduction}

Through much of our recent history, the United States has had an inconsistent and paradoxical approach to language learning. ${ }^{4}$

We are a proudly multicultural, polyglot nation, home to more than 350 languages. Yet we continually ignore opportunities to value, nurture, and sustain languages other than Englishopportunities that would greatly enhance our personal, cultural, professional, and civic lives, as well as the economic strength and security of our nation.

The United States has both driven and benefited from the spread of English globally. It is the most commonly taught language in the world by a factor of twenty. It is spoken in at least 101 countries and is a critical component of our commercial and diplomatic leadership. ${ }^{5}$ It is an official language of the United Nations, the World Trade Organization, the International Criminal Court, NATO, and the European Union. In short, the English language is a resource to be cherished and should continue to be an educational priority.

However, the dominance of English, to the exclusion of other languages, has also had adverse and often unforeseen consequences at home and abroad-in business and diplomacy, in civic life, and in the exchange of ideas. We often find ourselves left out of important conversations, misinterpreting what we hear, and failing to understand all-important nuances, precisely because we have undervalued languages other than English in our schools, our communities, and our own homes.

According to the U.S. Census Bureau, more than sixty-five million U.S. residents speak a language other than English at home-a number that has been growing decade by decade since the 1970 . Nevertheless, that number represents only 20.7 percent of the total population, and only a fraction of this cohort speaks, reads, and comprehends a second language well. ${ }^{6}$ The vast majority of American citizens remain monolingual.

Increasingly, policy-makers and business leaders are seeking to address the real costs associated with our nation's limited capacity in languages. For example:

For business: Almost 30 percent of the U.S. business executives who participated in a 2014 Coalition for International Education commissioned study reported missed opportunities abroad due to a lack of on-staff language skills, and nearly 40 percent reported that they had failed to reach their international potential due to language barriers.7 Business leaders are beginning to recognize that they are missing opportunities at home as well, especially in negotiations to attract foreign direct investment in the U.S. workforce, nearly 70 percent of which was channeled to the manufacturing sector in $2015 .{ }^{8}$ 
Several U.S. cities associated with the Brookings Institution's Global Cities Initiative are now examining the strategic value of local language capacities in attracting such investment, and researchers are now finding evidence that businesses across the country will offer higher salaries to bilingual employees. ${ }^{9}$

For science and technology: Language barriers impede the progress of science just as they impede business interactions. In one of the more startling recent examples, U.S. and other English-speaking scientists were late in recognizing the severity of the 2004 avian flu epidemic because the initial research on the disease was published in Chinese-language journals. ${ }^{10}$ In 2007, when Congress passed the America COMPETES Act to promote innovation in U.S. science and technology, it prioritized the need to increase "the opportunities to study critical foreign languages and the context in which the critical foreign languages are spoken; and ... the number of American students who achieve the highest level of proficiency in critical foreign languages."11 This commitment was, in part, a recognition that the nation's competitiveness in scientific and technological innovation would be improved if researchers were able to communicate and translate their findings internationally and to account for the work of scientists who reported their findings in non-English journals. ${ }^{12}$

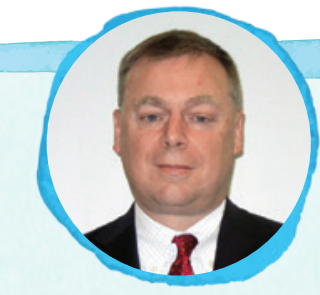

\section{Trevor Gunn, Ph.D.}

Vice President, International Relations, Medtronic, Inc.

Trevor Gunn is vice president of international relations for Medtronic, Inc., the world's largest medical technology company. He learned French in school and during trips to visit family in France, and Swedish as an exchange student while in high school. Gunn also took several college courses in Russian and became proficient as a result of his business interactions.

Gunn was formerly the long-time director of the Commerce Department's Business Information Service for the Newly Independent States (BISNIS), the clearinghouse for U.S. government information for doing business in the former Soviet Union. For twenty-two years, he has been an Adjunct Professor at CERES in Georgetown University's Walsh School of Foreign Service.

In his career, Gunn has worked with the Chamber of Commerce of Southern Sweden, Dover Elevator Corporation (now ThyssenKrupp of Germany), International Executive Service Corps, and on the staffs of the former San Francisco mayor and two U.S. senators from California. He received his bachelor's degree from the University of San Francisco and his Ph.D. in international relations from the London School of Economics.

"Through the eight languages I tried and the three languages in which I developed proficiency, the accumulated knowledge has allowed me to weave in and out of various countries professionally and with confidence. Knowing other languages has made me a significantly better negotiator and business partner, and contributed immensely to my professional growth and chosen path. Command of a foreign language puts you in charge of your future."13 
- For national security and international relations: In recent years, Congress and the Office of Management and Budget have held a series of hearings and issued several reports supporting the notion that the nation's language deficit has threatened priorities in national security, diplomacy, and economic competitiveness. In 2012, the U.S. Department of State increased the number of "language-designated positions" by 15 percent to help build and maintain "an effective civilian workforce that can fulfill its role in strengthening the security and prosperity of our Nation." ${ }^{14}$ At the same time, the Department of Defense requested that the nation's school systems train more language speakers at an earlier age, in part because it has now created over thirty thousand positions

\section{Estimate of Language Skills of U.S. Population Aged Five Years and Older, 2009-2013}

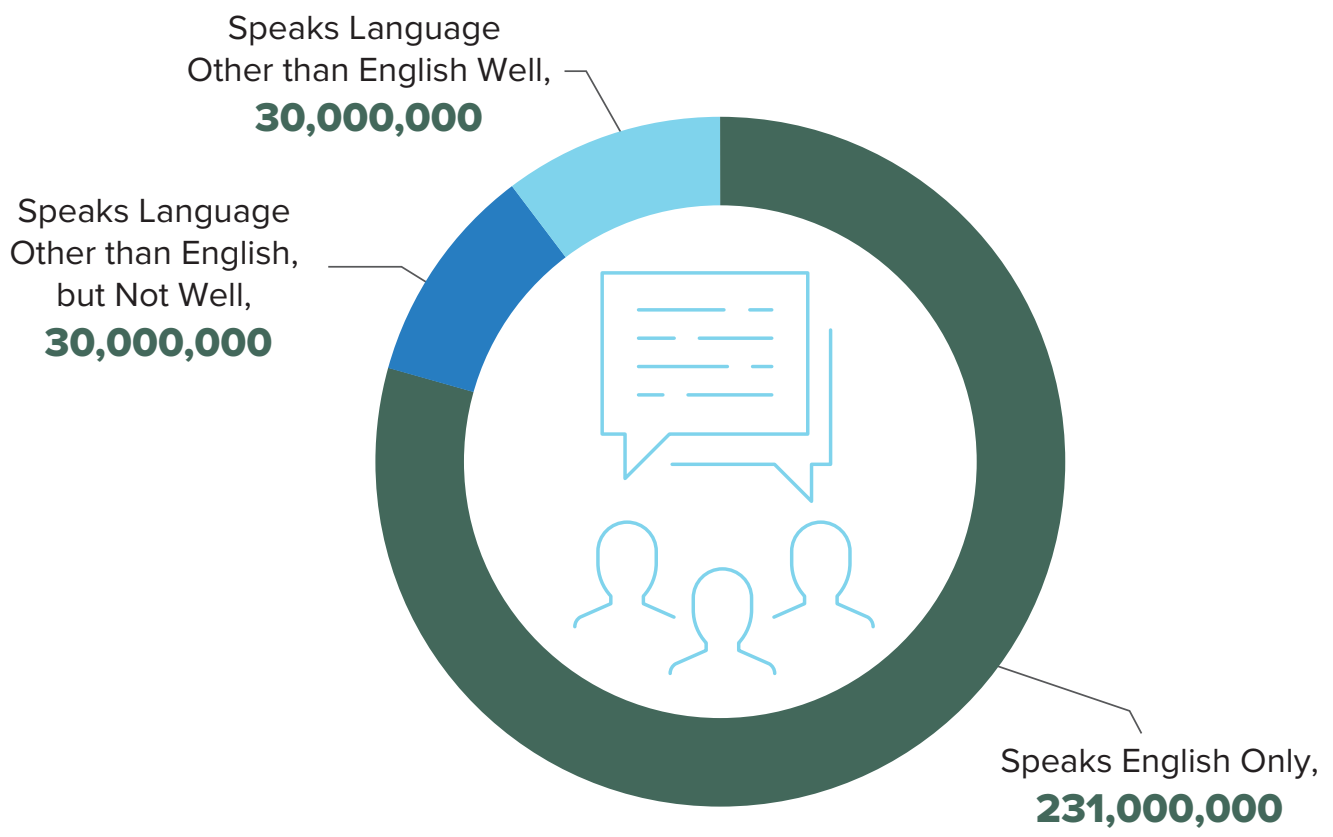

SOURCE: The estimate of the share of the total population that speaks a non-English language at home is based on the American Community Survey. See U.S. Census Bureau, "Detailed Languages Spoken at Home and Ability to Speak English for the Population 5 Years and Over for United States: 2009-2013," American Community Survey, October 2015, http://www.census.gov/data/tables/2013/demo/2009-2013-lang-tables.html. Estimate of skill levels of adults eighteen and older drawn from Tom W. Smith, Peter Marsden, Michael Hout, and Jibum Kim, General Social Surveys, 1972-2014 [machine-readable data file] (Chicago: National Opinion Research Center at the University of Chicago, 2016), http://gssdataexplorer.norc.org. 
that have a language requirement. ${ }^{15}$ And the Federal Bureau of Investigations, in response to the $9 / 11$ attacks, increased the number of language experts on staff by 85 percent, a significant investment that still may not meet its current needs. ${ }^{16}$ The message in each case was clear: effective communication is the basis of international cooperation, and a strong national defense depends on our ability to understand our adversaries as well as our friends. ${ }^{17}$

An expanded capacity in world languages is also a social imperative, and the provision of language access in the delivery of social services is mandated under Title IV of the Civil Rights Act of 1964 and the Affordable Care Act. ${ }^{18}$ Growing numbers of American citizens speak languages other than English, and in some major urban areas, as many as half of all residents speak a non-English language at home. ${ }^{19}$ But all too often, their access to vital services, including health care, and even their ability to exercise simple rights are limited not only by their inability to communicate in English, but by the inability of service providers to communicate, or to secure the services of those who can communicate, in languages

\section{Main Languages Spoken at Home by U.S. Residents Aged Five Years and Older, 2008-2010}

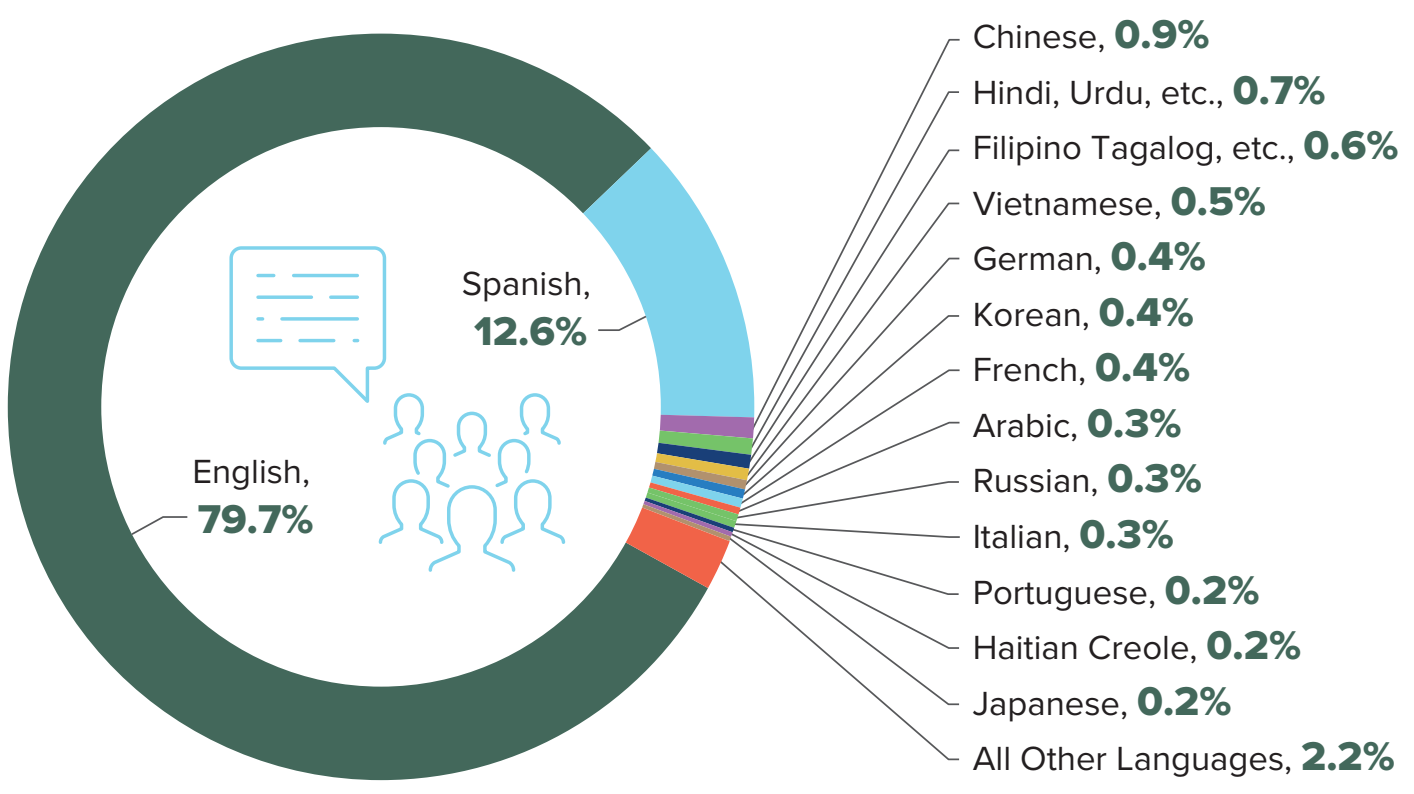

SOURCE: American Community Survey, 2008-2010 merged files, as quoted in Rubén G. Rumbaut and Douglas S. Massey, "Immigration and Language Diversity in the United States," Daedalus 142 (3) (Summer 2013): 146. 
other than English. ${ }^{20}$ For example, recent reports suggest that language barriers (including the scarcity of interpreters and the absence of forms and information in languages other than English) are a particular obstacle to due process in state and federal courts. ${ }^{21}$ We have an obligation to do better, by educating a pool of experts who read, write, and speak a wide range of languages, and by deploying them where they are needed most.

Although there are many challenges ahead, there are reasons to believe that the United States can overcome its language deficit. Linguistic diversity is deeply embedded in our history. The English we speak is only one of many European, Native American, African, and Asian languages that have been spoken on the North American continent. ${ }^{22}$ This diversity is a cherished part of our nation's past, a fact of our present, and a key to our future: a valuable asset in our relations with other nations and cultures and a benefit to our children as they grow up in an interconnected world. As the home of at least 350 languages in addition to English, we have a strong linguistic base and an unprecedented opportunity to engage other nations and cultures in ways that build lasting, mutually beneficial connections. ${ }^{23}$

Tapping this vast potential would have real benefits for our personal lives as well as for commerce, security, and diplomacy. Researchers are discovering that language learning, particularly among young children, improves learning outcomes in a variety of other disciplines over a long period of time. ${ }^{24} \mathrm{New}$ empirical evidence suggests that it also encourages the development of empathy and effective interpretive skills. ${ }^{25}$ Bilingualism enhances overall cognitive ability among the young and old alike, and may even help delay certain

\section{James Tobyne}

Strategic Partnerships \& Business Development, Alibaba.com

James Tobyne holds a bachelor's degree from Marquette University and a master of science in foreign service from Georgetown University. He was a Freeman Asia Scholar in Beijing and a U.S. Department of State Critical Language Scholar in Suzhou, in addition to completing language and cultural studies in Milwaukee and Taipei. Proficient in Mandarin Chinese, Tobyne is dedicated to promoting international trade, economic development, and cross-cultural communication. He has traveled professionally throughout the United States, Asia, and South America, working for organizations such as the US-ASEAN Business Council, Al Jazeera English, and Export Now. Before joining the e-commerce company Alibaba Group, he served as a Global Project Fellow for the D.C.-based Bertelsmann Foundation and an advisor and field researcher in Ulaanbaatar, Mongolia, for the Millennium Challenge Corporation.

"When I was in high school, I thought learning a foreign language was a complete waste of time and effort. Today, as an employee of one of the world's largest Internet companies, my language skills_including proficiency in Mandarin Chinese-are an essential component of my job." 26 
manifestations of aging. ${ }^{27}$ And anyone who has traveled abroad, conversed with a citizen from a different country, or communicated with a speaker of a different language in this country can attest to the ways in which language competency enriches life experiences and provides new opportunities for personal growth.

For all of these reasons, there is an emerging consensus among leaders in education and science, business and government, international relations and the military, and community organizations and nonprofits that English is critical but not sufficient to meet the nation's future needs, and that a greater public emphasis on language education would yield results far greater than any initial financial investments. ${ }^{28}$ In the pages that follow-the product of discussion and deliberation over eighteen months-the American Academy's Commission on Language Learning offers its findings and recommendations to improve the nation's language capacity. This report focuses on five basic goals:

Increase the number of language teachers at all levels of education so that every child in every state has the opportunity to learn a language other than English.

- Supplement language instruction across the education system through public-private partnerships among schools, government, philanthropies, businesses, and local community members.
Support heritage languages already spoken in the United States, and help these languages persist from one generation to the next.

- Provide targeted programming and additional support for Native American languages being used as primary languages of education.

- Promote opportunities for students of all ages to learn languages by experiencing other cultures and immersing themselves in languages as they are used in everyday interactions and across all segments of society.

In combination, these goals outline a strategy to improve language education so that every individual, as well as the nation as a whole, can share in the rewards and benefits of learning a language other than English. Schools, twoand four-year colleges, universities, community organizations, businesses, government agencies, philanthropists, students, and parents all have a role to play in advancing these goals. It is critical that we work together at this moment in history, when there is so much to gain by participating in a multilingual world, and so much to lose if we remain stubbornly monolingual. 


\section{One Vision for the Future}

The 2013 Languages for All initiative, organized by the University of Maryland Center for Advanced Study of Language in collaboration with several national and international language associations, has outlined reasonable attainment goals for the nation's future language learners.

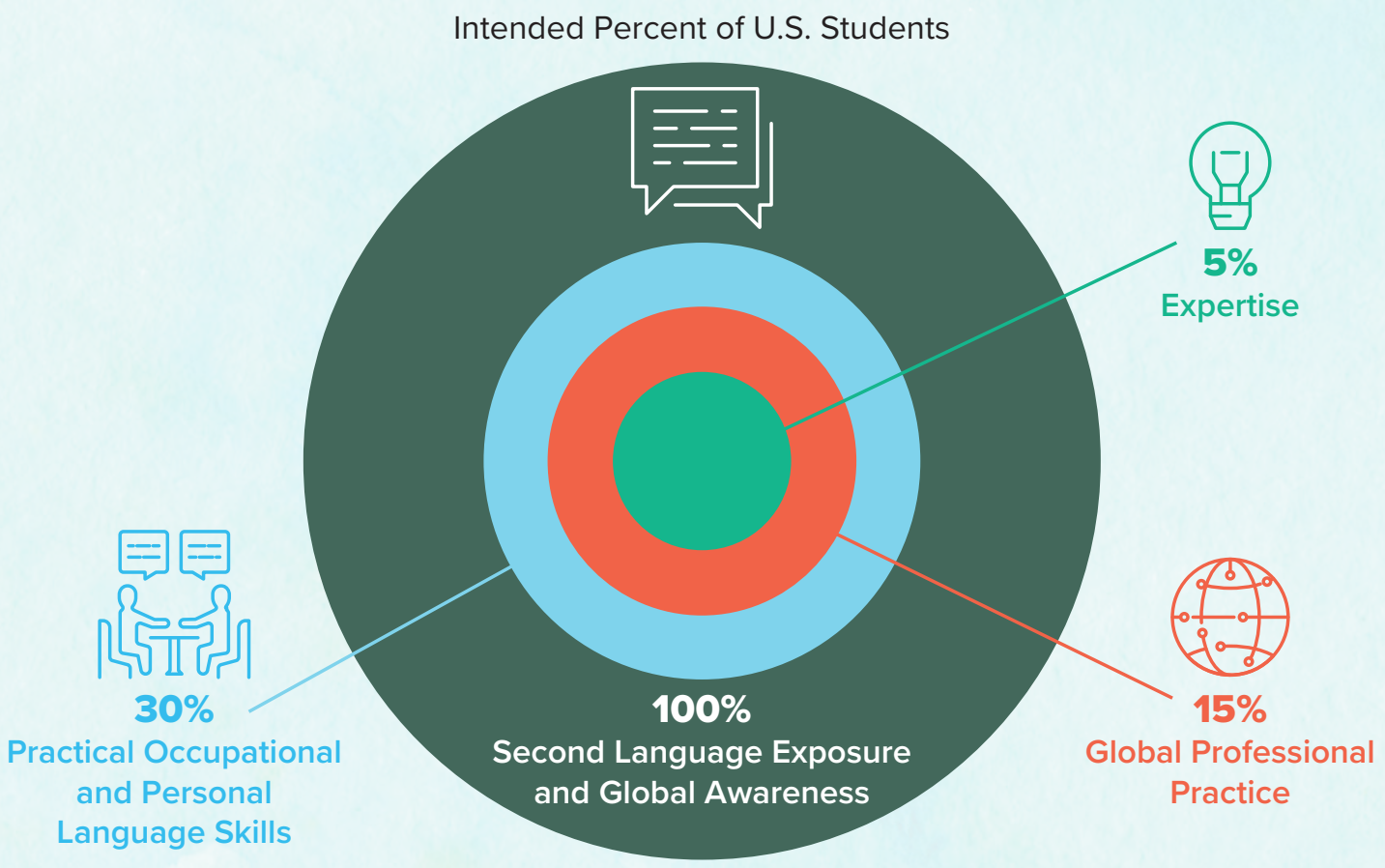

This vision of the future of language includes:

- 100 percent of learners in the U.S. education system exposed to international perspectives, cultures, and/or languages in order to inform life-long decisions about work and learning, and to support language and international efforts broadly in society. Of that group:

- 30 percent of learners will acquire basic language skills in order to work, for example, in the service industry and to travel freely;

- 15 percent of learners will acquire the global professional skills needed to practice at a high level internationally; and

- 5 percent will acquire expert skills in order to perform necessary research and to engage in international diplomacy.

SOURCE: Languages for All? (College Park: University of Maryland Center for Advanced Study of Language, 2013), accessible at http://www.americancouncils.org/sites/default/files/LFA2013_FinalReport.pdf. 


\section{Section 1: Building Educational Capacity}

According to the most recent data on language learning in the European Union, 66 percent of all European adults report having some knowledge of more than one language. ${ }^{29}$ The share of U.S. adults who report similar knowledge is closer to 20 percent, and very few speak, read, or write proficiently in a second language. ${ }^{30} \mathrm{An}$ estimated 300-400 million Chinese students are now learning English, compared with about 200,000 U.S. students currently studying Chinese. ${ }^{31}$ The geographical and historical circumstances in the United States are, of course, very different (as is the relative ease of mastering the twenty-six-character English alphabet), and the pressure to learn a second language is certainly less persistent in an English-speaking nation. China's commitment to English suggests that it has and will continue to have a special status among world languages, a status that gives the United States a competitive advantage in certain aspects of global trade and international exchange.

But the wide disparity between the European or Chinese approach to languages and the U.S. approach suggests that we, as a nation, are lagging in the development of a critical twentyfirst-century skill-and that we risk being left out of any conversation that does not take place in English. We can and should teach more languages to more people.

Functional ability in a second language comes in many forms and a range of skills, including lis- tening comprehension, speaking, reading comprehension, and writing - up to and including the ability to live and work abroad. Each skill set and level of ability is valuable, useful, and deserving of encouragement. The ultimate goal of any coordinated effort to improve language learning - for students, parents, school districts, states, and the nation as a whole-should not be a standardized pursuit of a particular level of competency, but rather improved access to language education for all U.S. citizens, irrespective of geography, ethnicity, or socioeconomic background. As children prove especially receptive to language education-they spend much of their time in educational settings and can develop language skills gradually throughout their lives-it is critical that language education begin at the earliest possible moment in the educational continuum. Therefore, this overarching goal can be expressed more specifically as a desire to see every school in the nation offer meaningful instruction in world and/or Native American languages as part of their standard curricula. Across the nation, there has been a significant decline in the number of middle schools offering world languages: from 75 percent in 1997 to 58 percent in $2008 .{ }^{32}$ Over the same period, there was a 6 percent decline in the number of elementary schools that taught languages other than English, from 31 percent to 25 percent; the outlook is particularly bleak in the nation's public elementary schools, only 15 percent of which offered a program for 
languages other than English, compared with more than 50 percent of private elementary schools. ${ }^{33}$ This disparity of access and opportunity, mirroring other forms of systemic inequality, must be addressed immediately, beginning with a recommitment by school administrators at public institutions in particular. Before- and after-school enrichment programs can be a useful supplement to classroom learning, and this Commission encourages the development of more programs through public-private partnerships and enhanced collaboration between schools and local communities. But the only way to ensure that every child has access is for every public school to offer language education as part of its standard course of instruction.

This is a tall order. School curricula are already overloaded and, over the past decade, STEM (science, technology, engineering, and math) education has been a national priority; but language must be seen as complementary to, rather than as competing with, STEM. But even if language learning becomes a national

\section{Share of Elementary Schools Teaching Languages Other than English, by Control of School, Academic Years 1986-1987 to 2007-2008}

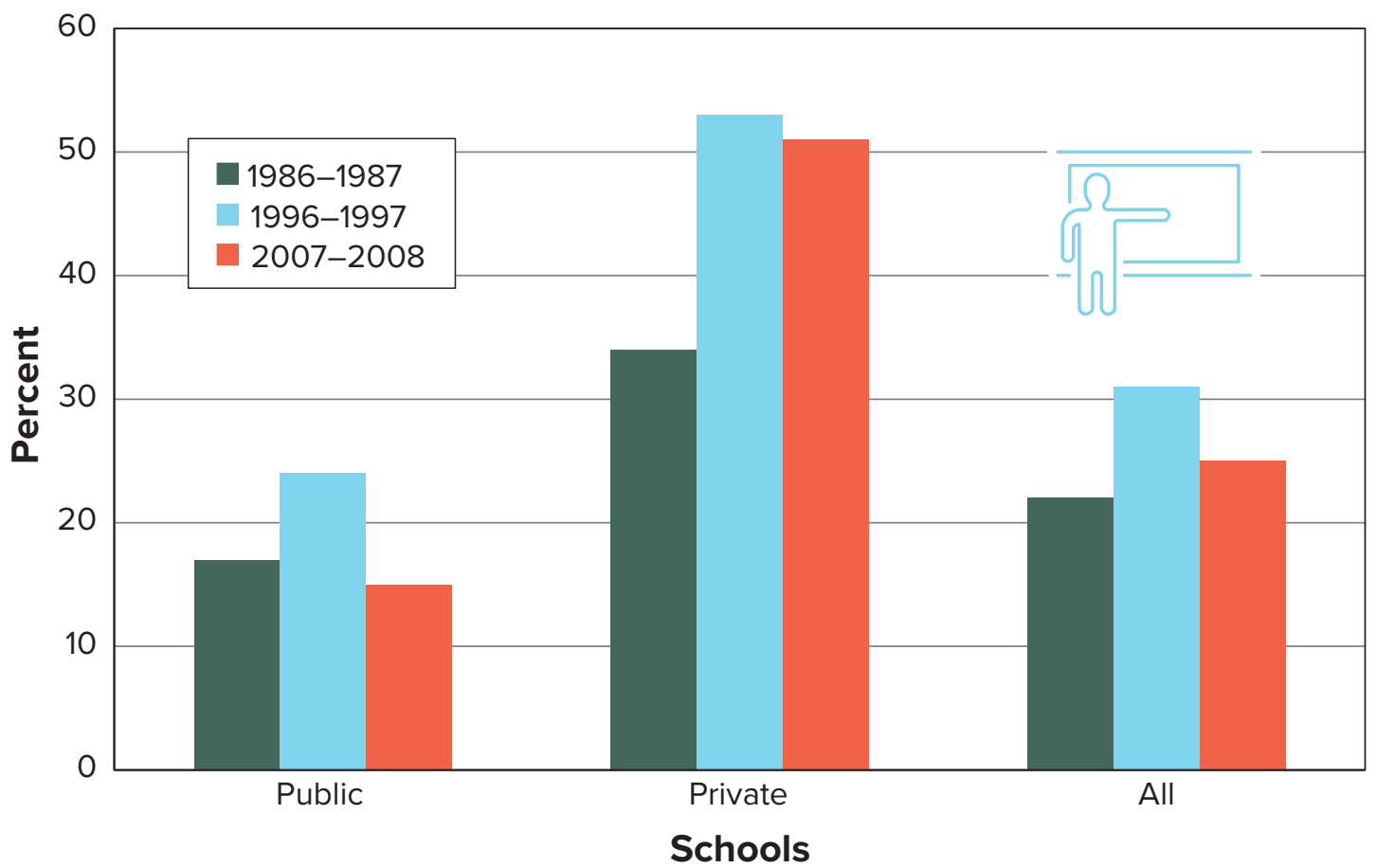

SOURCE: Nancy C. Rhodes and Ingrid Pufahl, Foreign Language Teaching in U.S. Schools: Results of a National Survey (Washington, D.C.: Center for Applied Linguistics, 2010), 22. 
priority parallel to the emphasis on STEM education, we do not have enough certified language teachers at any level to meet the demand. According to the U.S. Department of Education, forty-four states and the District of Columbia currently report a shortage of qualified $\mathrm{K}-12$ language and/or bilingual teachers for the 2016-2017 school year. ${ }^{34}$ Indeed, more states report a teacher shortage in languages than in any other subject. And since this count depends entirely on the states' self-reporting, the shortage may be even more significant than it appears.
This workforce issue is further complicated by a misalignment between the current infrastructure for language education and the emerging science of language acquisition. Language instruction in the United States typically begins in middle school or high school-a practice that ignores young learners when they are most receptive-when they have time to devote to their studies, when they are already in school and engaged in learning activities, and when they have a much longer timeline for developing their skills before they reach adulthood. Language

\section{Share of Secondary Schools Teaching Languages Other than English, by School Level, Academic Years 1986-1987 to 2007-2008}

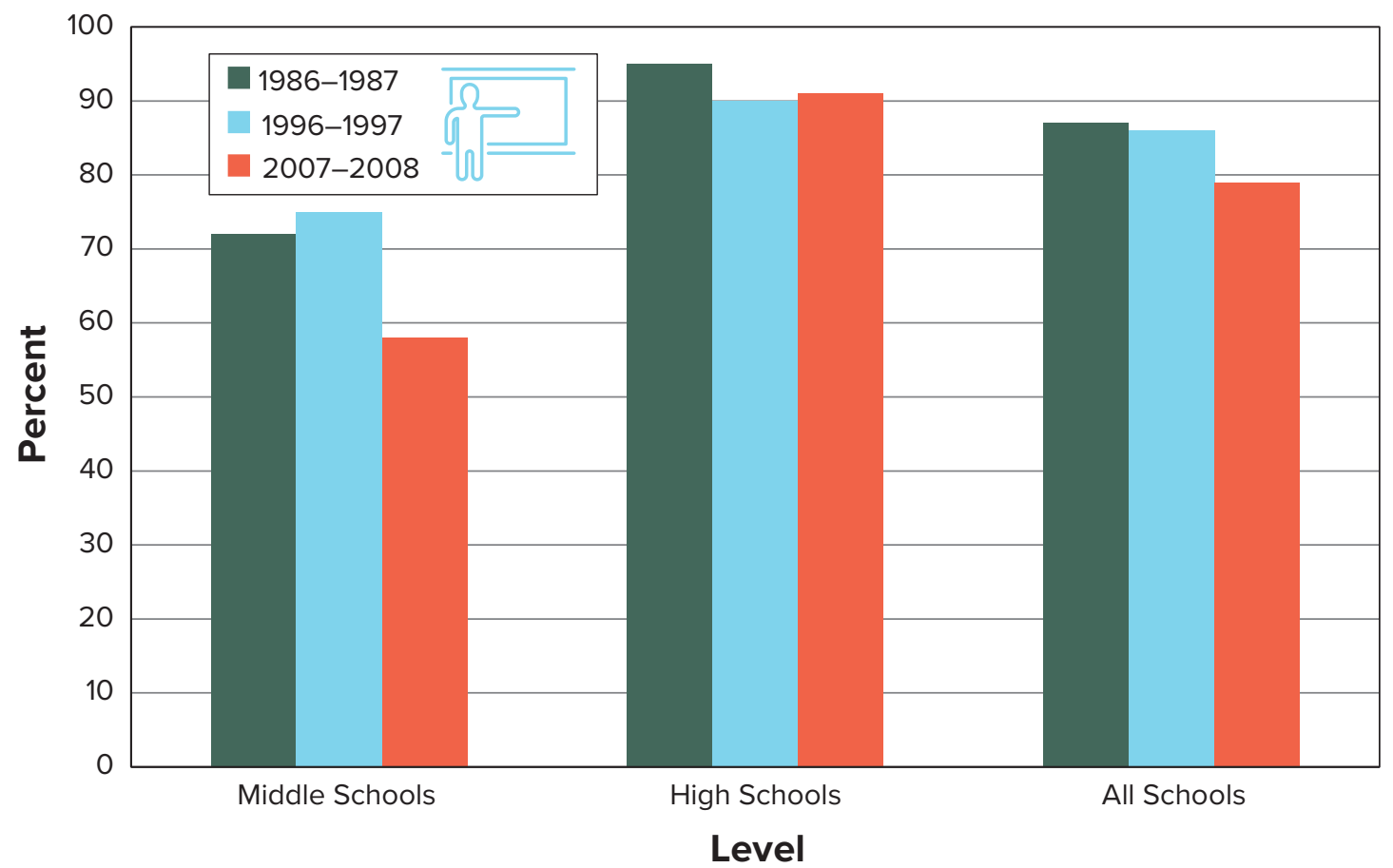

SOURCE: Nancy C. Rhodes and Ingrid Pufahl, Foreign Language Teaching in U.S. Schools: Results of a National Survey (Washington, D.C.: Center for Applied Linguistics, 2010), 23. 
instruction should therefore begin much sooner in U.S. schools, even as early as preschool. The structural challenges to such an adjustment are significant, including the need for system-wide staffing and curricular changes, but the benefits would be immediate and far-reaching.
Digital technologies can help address at least some of these challenges. Blended learning models, through which students receive some part of their curriculum digitally-often through practice exercises, video, or interactive games-are particularly beneficial in communities with a short supply of language teachers.

\section{Share of All K-12 Students Enrolled in Language Courses Other than English, by State, 2014-2015}

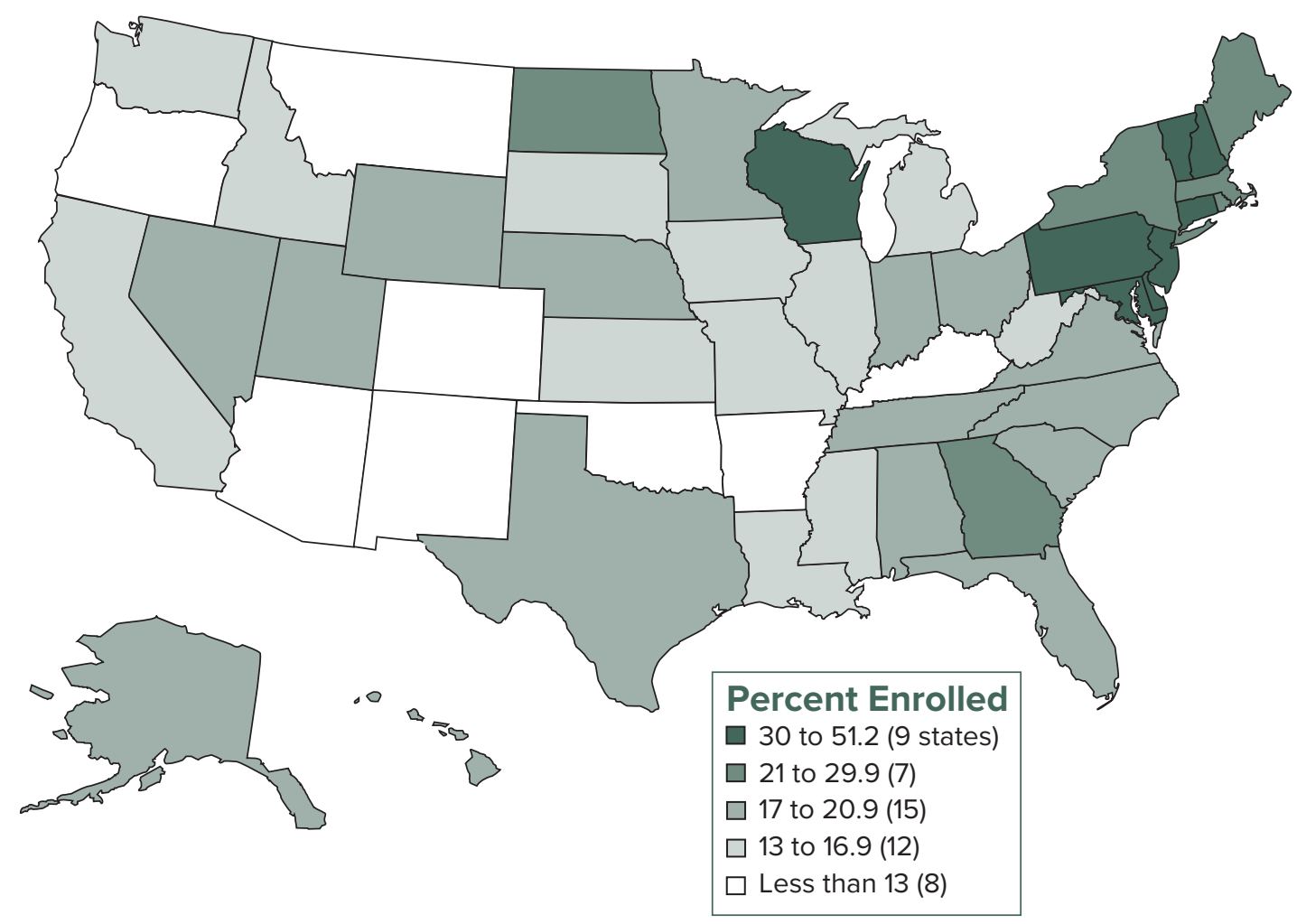

SOURCE: American Councils for International Education, American Council on the Teaching for Foreign Languages, Center for Applied Linguistics, and Modern Language Association, The National K-16 Foreign Language Enrollment Report 2014-15 (Washington, D.C.: American Councils for International Education, 2016), http://www.americancouncils .org/national-k-16-foreign-language-enrollment-report. Statistics on European students from Eurostats, "Foreign Language Learning Statistics," September 2016, http://ec.europa.eu/eurostat/documents/2995521/7662394/3-23092016 -AP-EN.pdf/57d3442c-7250-4aae-8844-c2130eba8e0e. 
Young children have proven especially responsive to programs that alternate between personal instruction and online enrichment. ${ }^{35} \mathrm{By}$ creating international exchanges over Facebook and Instagram, and even direct communication with students in other countries over Skype, many $\mathrm{K}-12$ teachers have incorporated social media into their lesson plans as a way to explore other countries without having to travel. In addition, an emerging category of lan-

\section{A Note about Data}

Many states already collect data about math and science enrollments for $\mathrm{K}-12$ education in order to better understand and manage which students have access to subject matter within public academic settings. In response to national surveys and direct requests, some states can provide data about language learning, but there is no mandate for the consistent collection and maintenance of such data, as there often is in other disciplines. State and federal policy-makers could develop more informed educational and curricular goals for language learning if:

- Data were collected at scheduled intervals, allowing for closer monitoring of total enrollment and the distribution of enrollment among languages and grade levels; and/or

- Collection were standardized across states to provide a greater understanding of the state of language learning across the nation.

Such data collection efforts could yield important information about student demographics, teacher qualifications and expertise, and the types of instruction available around the nation. It might also help inform the development of student performance metrics. guage apps for computers and smartphonesLingua.ly, Quizlet, Memrise, Duolingo, and GraphoGame, for example-are introducing world languages to students on their own time. These apps are a promising gateway for learners of all ages and an exciting new subject for research about the efficacy of technological innovation in language instruction.

Over the coming decades, progress in language education will continue to be influenced by advances in technology and research including:

Artificial intelligence and deep learning, through which computers process multiple layers of data;

"Big data" solutions to learning and instruction;

Translation assistance;

- Cognitive technologies that mirror human processes, like speech recognition and natural language processing;

- Human-systems interface design, which govern the ways humans and machines interact; Systems for gestural, eye movement, and audio-visual (including facial) recognition;

- Low-cost microphone arrays and noise reduction circuitry for improved voice recognition; and

- The localization of speech in noisy, realworld environments.

Apple's Siri, Amazon Echo, Google Home, and IBM's Watson already combine many of these technologies, and we can expect more advancements and improvements in the near future. Critical to all of these developments will be our continued support for research-already underway on university campuses and in labo- 
ratories across the nation-in a variety of areas, including linguistics, education, second language acquisition, computer science and artificial intelligence, cognitive science, and electrical engineering.

Such technology should play a supportive role and can even be a motivating factor in encouraging more people to learn more languages. In many ways, there have never been more available options for pursuing a second language. But technology should not be seen as a replacement for the sound principles of second language acquisition. Any successful program in language education requires at least some direct communication with a qualified instructor who can teach complicated concepts like context, speaker intent, and shades of meaning. Each state should therefore commit to increase the number of language teachers in $\mathbf{P}-12$ education so that every child in every state has the opportunity to learn a language other than English in an academic setting, whether the child is experiencing a second language for the first time, mastering a language he or she already speaks at home, or attending a school taught in a Native American language.

Given the dearth of available data about language instruction at the state level, it is difficult to assess the exact size of the national teacher shortage. Forty-four states report that they cannot find enough qualified teachers to meet current needs, but record-keeping has been regrettably imprecise, in part because every school district in the nation responds to the teacher shortage in its own way (by cutting classes, by combining classes, by contracting before- or after-school enrichment programs, to name a few). We do not have sufficient information

\section{The Cognitive Benefits of Language Learning}

Recent studies have suggested that language learners derive myriad secondary benefits from language instruction.

- The September 2013 issue of the Journal of Experimental Child Psychology analyzed two studies that found that bilingual children have stronger working memorythe ability to retain and manipulate distinct pieces of information over short periods of time-than do monolingual children. ${ }^{36}$

- A 2013 assessment of the Utah Dual Language Immersion program showed that children in the program gained improved memory and attention, problem-solving capabilities, primary-language comprehension, and ability to empathize with other cultures and people. ${ }^{37}$

- A study in the September 2009 issue of Cognition showed that bilingual children have greater executive functioningfocus, planning, prioritization, multitasking -than monolingual children. ${ }^{38}$

- A 2015 study published by researchers from the University of Chicago in Psychological Science showed that "multilingual exposure may promote effective communication by enhancing perspective taking," a fundamental component of empathy. ${ }^{39}$

- A 2007 study published in Neuropsychologia suggests that bilingual patients at a memory clinic presented dementia symptoms four years later, on average, than their monolingual counterparts. A similar study in Neurology found that bilingualism delayed the onset of Alzheimer's disease. ${ }^{40}$

Scientists are just beginning to study the cognitive benefits of language learning. Continued support for research will help to verify these benefits and identify the most promising directions to pursue. ${ }^{41}$ 


\section{The Seal of Biliteracy}

The Seal of Biliteracy is an award presented by a state department of education or local district to recognize a student who has attained a state-determined proficiency in English and one or more other world languages by high school graduation. The second language can be a native language, heritage language, or a language learned in school or another setting. The Seal becomes part of the student's high school transcript and diploma, a statement of accomplishment that helps to signal a student's readiness for career and college, and for engagement as a global citizen.

The Seal of Biliteracy program began in California, as a collaboration between Californians Together and the California Association of Bilingual Educators, and guidelines for the Seal have been developed jointly by the American Council on the Teaching of Foreign Languages (ACTFL), the National Council of State Supervisors for Languages (NCSSFL), the National Association of Bilingual Education (NABE), and the TESOL International Association. Twenty-three states and the District of Columbia now offer a state Seal of Biliteracy. We urge more states to adopt the Seal.

about these district-level responses to attach a specific number to the national teacher shortage, and encourage any study that advances our knowledge of its size and scope. Nevertheless, we can infer from current hiring initiatives that the need is great and can only be met through a series of efforts involving federal, state, and local cooperation as well as international partners and new incentives. The Dallas Independent School District adds a \$3,00o annual stipend to a typical teacher salary to attract new multilingual teachers, and hires as many as five hundred bilingual teachers each year. ${ }^{42}$ Presi- dent Barack Obama's 1 Million Strong initiative, a partnership with Chinese president Xi Jinping to expand the number of U.S. K-12 students learning Mandarin Chinese to one million, includes a goal of recruiting and certifying five thousand new teachers by 2020.43 U.S. mainland schools recruited almost sixteen thousand teachers from Puerto Rico between 2008 and 2013. ${ }^{44}$ And these numbers only begin to outline the scope of the national need.

Nevertheless, several efforts that are already underway, including state-level language initiatives in Utah and Delaware, have proven that it is possible to focus on language learning as an educational priority. More states should follow their lead.

Drawing on decades of innovation in world language education in Europe, Asia, and the United States, as well as the long history of federally mandated language education efforts for children who do not speak English, the Utah state senate passed the International Education Initiative in 2008.45 The Initiative made funding available for dual language immersion in Chinese, French, Spanish, and, a few years later, Russian and Portuguese. At the same time, Governor Jon Huntsman, Jr., led the creation of a $\mathrm{K}-12$ language roadmap for Utah to address the needs for language skills in business, government, and education. Six years later, at least thirty thousand students were enrolled in immersion programs (in which half the day's teaching takes place in a language other than English), most beginning in the first grade. ${ }^{46}$ The results have been startling: over 80 percent of students participating in dual language immersion programs are functioning in their second language by the third grade, and 
the Utah state legislature reports that such students appear to score higher on standardized tests in English language arts as well as math, when compared with students not enrolled in dual language immersion programs. ${ }^{47}$

Following Utah's success, Delaware became the second state to implement dual language immersion programs when, in 2011, Governor Jack Markell set aside $\$ 1.9$ million in the state's annual budget for programs in Spanish and Mandarin Chinese and set the goal of enrolling ten thousand primary and secondary school students in these programs by 2022 . Indiana, Rhode Island, and Virginia have established pilot programs..$^{48}$ California residents have recently voted to approve Proposition 58, empowering public schools to create bilingual and multilingual programs for the first time since 1998.49 And the New York City Department of Educa- tion has committed $\$ 980$, ooo in federal funding to thirty-eight new $\mathrm{K}-12$ bilingual programs for the 2016-2017 school year, including twentynine dual language and nine transitional bilingual educational programs, serving more than 1,200 students..$^{\circ}$ Given all of the financial and social pressures on such a large, urban school district, New York's commitment is particularly noteworthy as affirmation of the need for more language education in the twenty-first century, and as proof that more is possible even under the most challenging circumstances.

These initiatives are models for the rest of the nation. But they are not scalable unless schools in other parts of the country can find and hire enough qualified teachers to teach more students.

One way to address teacher shortages directly is to distribute available talent more effectively.

\section{The Benefits of Dual Language Immersion}

A recent study of students in dual language immersion programs, which controlled for factors such as socioeconomic disparity, found that in a randomized selection of students, those who participated in dual language immersion programs achieved higher English language arts performance in dual immersion classes than those who did not. By the time dual language immersion students reached the fifth grade, they were an average of seven months ahead in English reading skills compared with their peers in nonimmersion classrooms. By the eighth grade, students were a full academic year ahead, whether their first language was English or another world language. These findings suggest that learning a second language helps students tackle the nuances and complexities of their first language as well.

In many cases, dual language immersion programs are also more cost-effective than other kinds of language courses. Rather than adding additional units to an already crowded curriculum, or requiring new teachers dedicated only to language instruction, immersion courses incorporate language instruction into preexisting coursework (in math, science, reading) and rely on the same teachers who teach other subjects. ${ }^{51}$ However, they also require teachers who can teach a broad curriculum in two languages, a challenge, at least in the short-term, for many school districts around the country. 
In addition, teacher education programs need to focus on recruiting more students into this specialty. And two- and four-year colleges and universities must ensure that future teachers -indeed any student who requires or wishes to pursue intermediate or advanced proficiency in a language-can find the courses they need. Language programs were particularly vulnerable during the Great Recession: many administrators, faced with difficult budgetary decisions, sacrificed language courses and requirements in order to preserve other disciplines. 55 These

\section{Language Consortia in Higher Education}

Given the number and diversity of world languages-as well as variations in student interest, the availability of faculty, and research capabilities-two- and four-year colleges and universities face a significant challenge as they try to provide education in as many languages as possible. A growing number are now sharing faculty and resources to make more languages accessible to students:

The Big Ten Academic Alliance, a consortium of fourteen universities, uses its distance-learning CourseShare program to offer online classes in nearly sixty-five less commonly taught languages, including Uzbek and Dutch, to students at all of its member universities. ${ }^{56}$

The Five College Center for the Study of World Languages offers academic year courses in less-commonly studied languages for students at Amherst, Hampshire, Mount Holyoke, and Smith Colleges, and the University of Massachusetts Amherst. Course sessions meet on all five campuses and are part of a student's regular course load. 57

The Association of Independent Colleges and Universities of Rhode Island Language Consortium Program allows students currently enrolled in an undergraduate degree program at one of Rhode Island's private institutions of higher education to enroll in language courses at any of the participating consortium schools in those courses that are not offered at their home institution. 58

The UNC-NC State Language Exchange affords students the opportunity to enroll in courses (and attend through video conferencing) at campuses other than their home campus.
Currently five language-specific exchanges exist: Greek-Latin, German, Russian, Portuguese, and Spanish. A sixth exchange called World Languages has been created to manage introductory courses in less commonly taught languages. 59

The Shared Course Initiative is a collaborative arrangement among Columbia, Cornell, and Yale to offer via videoconferencing coursework in several languages that are not otherwise taught on a particular campus. The courses are taught "live" by an instructor at one institution; students attend a regular class in a designated classroom outfitted with videoconferencing technology. ${ }^{60}$

The National Coalition of Native American Language Schools and Programs brings together programs, public and private schools, tribal colleges, and other institutions of higher education that teach coursework through Native American languages at all levels, with extensive connections to other tribal-college and tertiary programs supporting education through Native American languages. The Coalition supports teaching in fifteen states and offers assistance to groups seeking to start programs in these and other states and American territories. ${ }^{61}$ 
cuts did not always serve the best interests of students, who can reap professional rewards for achieving even moderate proficiency in a second language. ${ }^{62}$ Nor do they serve the interests of a nation that requires an everlarger cadre of bilingual citizens to maintain its place in the international community. Rather than eliminate programs or requirements, two- and four-year colleges and universities should find new ways to provide opportunities for advanced study in languages, through a recommitment to language instruction on campus, blended learning programs, and the development of new regional consortia that allow colleges and universities to pool language resources. ${ }^{63}$ Blended learning programs and consortia will be particularly important as

\section{Educating Students in Native American \\ Languages}

\section{CASE STUDY: HAWAII}

In 1986, there were fewer than fifty children under age eighteen proficient in Hawaiian, and Native Hawaiian educational achievement had plummeted. Beginning in 1987, the state public schools incorporated children and methodologies from private, nonprofit schools called Pūnana Leo (language nests) in which classes are taught in Hawaiian. State data for 2013-2015 indicate that students from these schools are now graduating from high school on time at a rate of 3 percent above the state average and 8 percent above the Native Hawaiian average, and the classes of 2014 and 2015 attended college directly out of high school at a rate 15 percent above the Native Hawaiian average. ${ }^{64}$ we increase the number of learning opportunities in less commonly taught languages like Arabic, Persian, and Korean. Only by maintaining such offerings in higher education can we ensure that we will have the teachers and linguistic and cultural experts we need for life and work in the twenty-first century.

Some colleges and universities, including Bryn Mawr, Princeton, and Yale, have instituted mandatory language study for undergraduates. They recognize Advanced Placement coursework as a qualification for higher-level language courses, rather than an exemption from language requirements. Not every college or university has the resources to institute such a policy immediately, but it is a laudable goal and worthy of serious consideration.

In addition, there are particular challenges in developing teachers of Native American languages. Until passage of the NALA in 1990, there was no official federal policy in support of Native American languages, and Native American languages were largely excluded from the nation's classrooms. As a result, the majority of Native American languages are spoken primarily by tribal elders. Few materials exist to teach Native American languages at any level, including at the tertiary education level. More college programs are needed to develop high proficiency in Native American languages along with Native American language teacher training programs. These might be developed through cooperative work among those relatively few universities and colleges, including tribal colleges and universities, that teach Native American languages. 


\section{Federal Funding for Language Learning}

At least twenty federal departments and agencies support research and development in language and communication technologies, including the Departments of State, Defense, Agriculture, and Health and Human Services, as well as the National Endowment for the Humanities and the National Science Foundation. The federal government also provides direct support for language education through the following acts of Congress, administered through the Department of Education:

\section{EVERY STUDENT SUCCEEDS ACT}

The Every Student Succeeds Act (ESSA), the reauthorization of the Elementary and Secondary Education Act (ESEA), was signed into law in 2015. The rewrite consolidated the most substantial K-12 foreign language programming at the Department of Education (the Foreign Language Assistance Program) into a state block grant called the Student Support and Academic Enrichment (SSAE) grants program. SSAE grants fund well-rounded education, efforts to improve school conditions and health, and strategies to promote the use of technology in schools. This program provides school districts with the option to fund language programming, but it remains unclear whether the appropriations committees will direct funding toward the initiative during FY 2017 or whether school districts will choose to direct this funding toward languages or a myriad of other uses. But the Act does present other funding opportunities:

- It is possible that school districts could use federal funding from Titles I and II for language education in support of "wellrounded" programming.

- Title III funding could be used to support language programs that also serve English Learners.

- A new, competitive Native American and Alaska Native Language Immersion Program is authorized at \$1.1 million under Title VI of ESSA.

\section{HIGHER EDUCATION ACT}

The Higher Education Act (HEA) was most recently reauthorized in 2008 . Higher education funding for foreign languages falls under Title $\mathrm{VI}$ of the HEA and includes international education programs and foreign language studies, both domestically and internationally. Administered by the Department of Education's Office of Postsecondary Education, these domestic programs are intended to strengthen language capability, and grants are awarded competitively to help fund centers, programs, and fellowships. Funding for domestic programs was reduced from $\$ 66.6$ million to $\$ 63.1$ million in FY 2013. However, funding has remained flat at \$65.1 million from FY 2014 to FY 2016.

The Department also administers the FulbrightHays programs. These international programs are permanently authorized under the Mutual Educational and Cultural Exchange Act of 1961, and are designed to provide participants with first-hand overseas experience, increase the interaction between Americans and citizens from other countries, and strengthen language skills. ${ }^{65}$

In both the Title VI and Fulbright-Hayes programs, priority is given to students studying less-commonly taught languages.

The program funding was reduced in FY 2013 from $\$ 7.5$ million to $\$ 7.1$ million, but has remained constant since then. As of this writing, the funding levels for both domestic and international programs for FY 2017 have not been announced.

A twenty-first-century education strategy that promotes broad access, values international competencies, and nurtures deep expertise in world languages and cultures will require increases in these funding streams. ${ }^{66}$ 


\section{Section 2: Involving Local Communities, Businesses, and Philanthropies}

While state and federal initiatives often offer the most efficient and scalable solutions to the challenge of improved language education, some useful and effective alternatives may not require the full authority and infrastructure of government programs. Language teacher associations play a central role in fostering communication across the teaching profession, supporting research, distributing teaching materials, and providing opportunities for professional development. A variety of international organizations also support the study and teaching of world languages, including Alliance Français, Goethe House, Hanban, International Korean Educators Network, Japan Foundation, Qatar Foundation, and Russkiy Mir Language Center, among others. But very often, schools need look no further than their local communities for new teaching and learning opportunities. Urban schools in particular are surrounded by valuable, untapped resources to enhance language and cultural education for all students: ethnic, immigrant, and Native American communities that conduct everyday business in languages other than English. Districts should experiment and search for ways to bring these language communities into the education system.

A number of innovative public-private partnerships have already been established in communities around the nation. For example, the Chicago Public Schools system supports a flourishing Arabic language program, guided by the Center for Arabic Language and Culture, that draws on the local Arab-speaking populations as well as support from local and international businesses and the Qatar Foundation International to supplement classroom learning. ${ }^{67}$ In New York City, the French Heritage Language Program of the FACE Foundation, in partnership with the French Embassy and the International Network for Public Schools, provides free French classes and cultural activities to students from ten city high schools, including immigrant students from French-speaking West Africa and Haiti. ${ }^{68}$ Typically, such programs-like the more formal heritage schools that have developed over the last few decadesrely on parental contributions as well as private support, in which schools, philanthropists, and businesses pool resources to address the needs of specific locations. Supplementing state-wide curricula, these programs can be responsive to local populations and creative in ways that state-driven programs cannot.

State humanities councils have also been successful in organizing educational activities, publishing books in languages other than English, and generating public excitement about cultural and linguistic diversity. There are fifty-five councils in the United States and its territories, each funded in part by the National Endowment for the Humanities, to promote humanities education and programming. Most sponsor programs that focus on local languages and many place a particular emphasis on the education of young children. Examples of such programs include: 


\section{Section 3: Developing Heritage Languages and Revitalizing Native American Languages}

The United States need look no further than its own immigrant, ethnic, and Native American communities to find the seeds of a rich and diverse linguistic future. As of 2006, the most recent year for which such data are available, the overwhelming majority of U.S. adults who reported that they spoke a language other than English-including 37 million Spanish speakers and 2.9 million Chinese speakers-acquired that language at home. ${ }^{74}$ In most cases, language acquisition is associated with familial, cultural, and historical ties, rather than school-based curricula. In an immigrant nation like the United States, this circumstance should be considered an asset. Heritage speakers have a working knowledge of a second language even before they enter the classroom. Prior to any educational investments at the local, state, or federal levels, they have a head start in achieving the kind of biliteracy that would be as beneficial to them individually as it would be to the nation as a whole. Undoubtedly, they can only become proficient in their heritage languages through persistent study and ongoing instruction. But if we encourage them in this pursuit, by supporting the heritage and Native American languages already spoken in communities across the nation and helping these languages persist from one generation to the next, we would have the nucleus of a truly multilingual society.

Unfortunately, immigrant communities find it difficult to maintain their proficiency in heritage languages once they enter the United States. A study in Southern California found that language proficiency falls quickly in each generation after the first to enter the country. More than 45 percent of the immigrants in the study who arrived as children under the age of thirteen were able to speak and understand a non-English language well (though they are not necessarily literate in these languages). By the third generation, fewer than one in ten were able to communicate well in their heritage languages. ${ }^{75}$

By developing strategic frameworks for Native American and heritage language learners and systematic, on-going instruction in heritage languages, schools can play an important role in reversing this trend. They should provide more language opportunities for Native American language learners and heritage speakers in classroom or school settings, allow heritage speakers more chances to exercise their heritage language in non-English language courses like social studies and science, and offer students designated times when they can meet and speak to other students who are heritage speakers. Some districts and states are already piloting such programs. For example, Sealaska Heritage, a nonprofit based in Juneau, Alaska, partners with Juneau schools to teach Southeast Alaskan native languages, like Tlingit, and has established a program to train teachers in local languages. ${ }^{76}$ The Maine French Heritage Program sponsors after-school language and culture activities in Lewiston and Augusta for students from French-speaking backgrounds 
in grades one through six. ${ }^{77}$ And the school district in Beardstown, Illinois, is developing a high school immersion program that is specifically designed to support a student population that is 70 percent heritage Spanish speakers. ${ }^{78}$

Similarly, more two- and four-year colleges and universities should make available curricula designed specifically for Native American languages and heritage speakers, and should find ways to offer credit for proficiency in a heritage language. As in $\mathrm{K}-12$ education, some colleges and universities are already experimenting with such curricula. The Spanish Heritage Language Program at the Uni- versity of Houston offers specific courses for heritage Spanish speakers; students who have successfully completed the intermediate level in this program fulfill the university's foreign language requirement and are encouraged to enroll in more advanced classes. ${ }^{79}$ The Universities of Arizona, Washington, and Oregon all support similar programs, providing new contexts for students' personal and cultural experiences; locating the Spanish spoken at home within a broader Spanish-speaking world; and featuring service-learning opportunities in local Spanish-speaking communities. ${ }^{80}$ And Columbia University introduced a dedicated track for heritage Russian speakers

\section{Where English-Speaking Adults Who are Fluent in Another Language Acquired the Non-English Language, 2006}

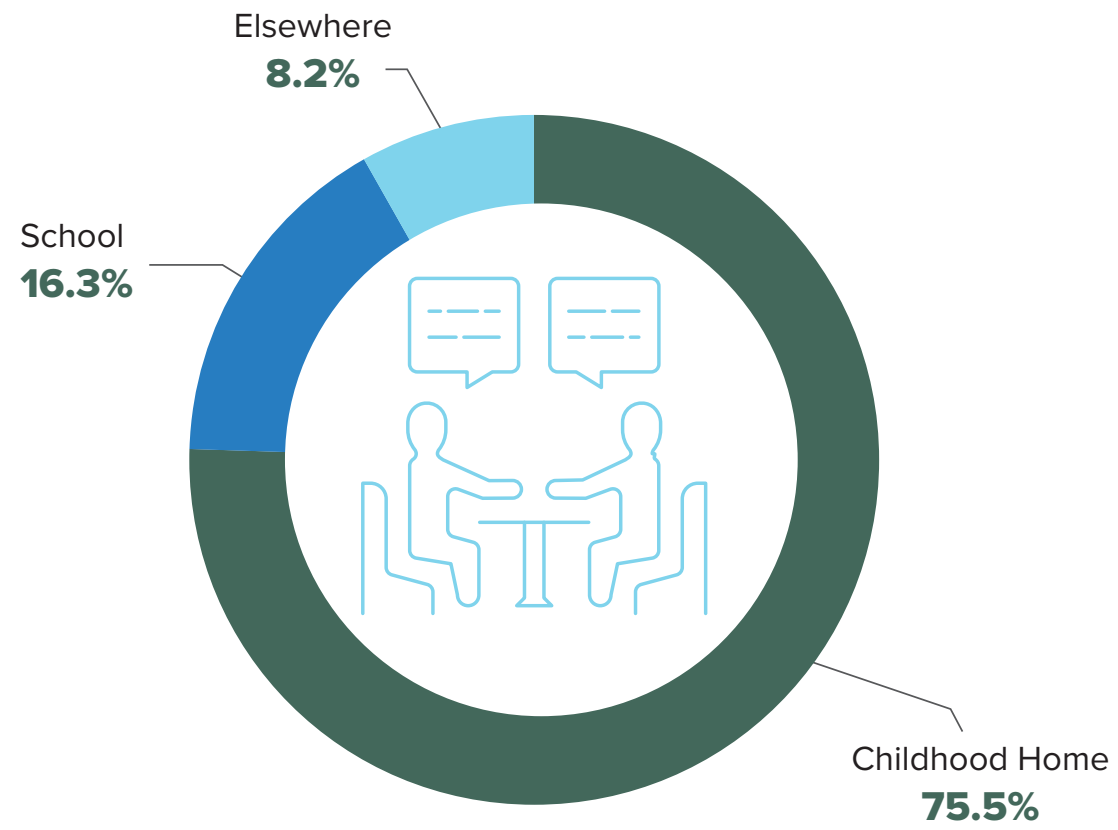

SOURCE: Analysis of data collected by the National Opinion Research Center at the University of Chicago in the General Social Survey for the Humanities Indicators. 
that brings limited-proficiency students to an advanced level in their heritage language in two semesters, while satisfying the university's undergraduate second language requirement. ${ }^{81}$ Each of these programs offers a model that can be adopted elsewhere and applied to other heritage languages.
Heritage language initiatives at schools and colleges are important, in part, because they recognize forms of self and cultural expression that have been devalued by our educational policies and practices, sometimes to devastating effect. For example, many students who are proficient in English as well as in a heritage language

\section{Dimensions of Non-English Language Proficiency, by Generation, in Southern California, 2001-2004}

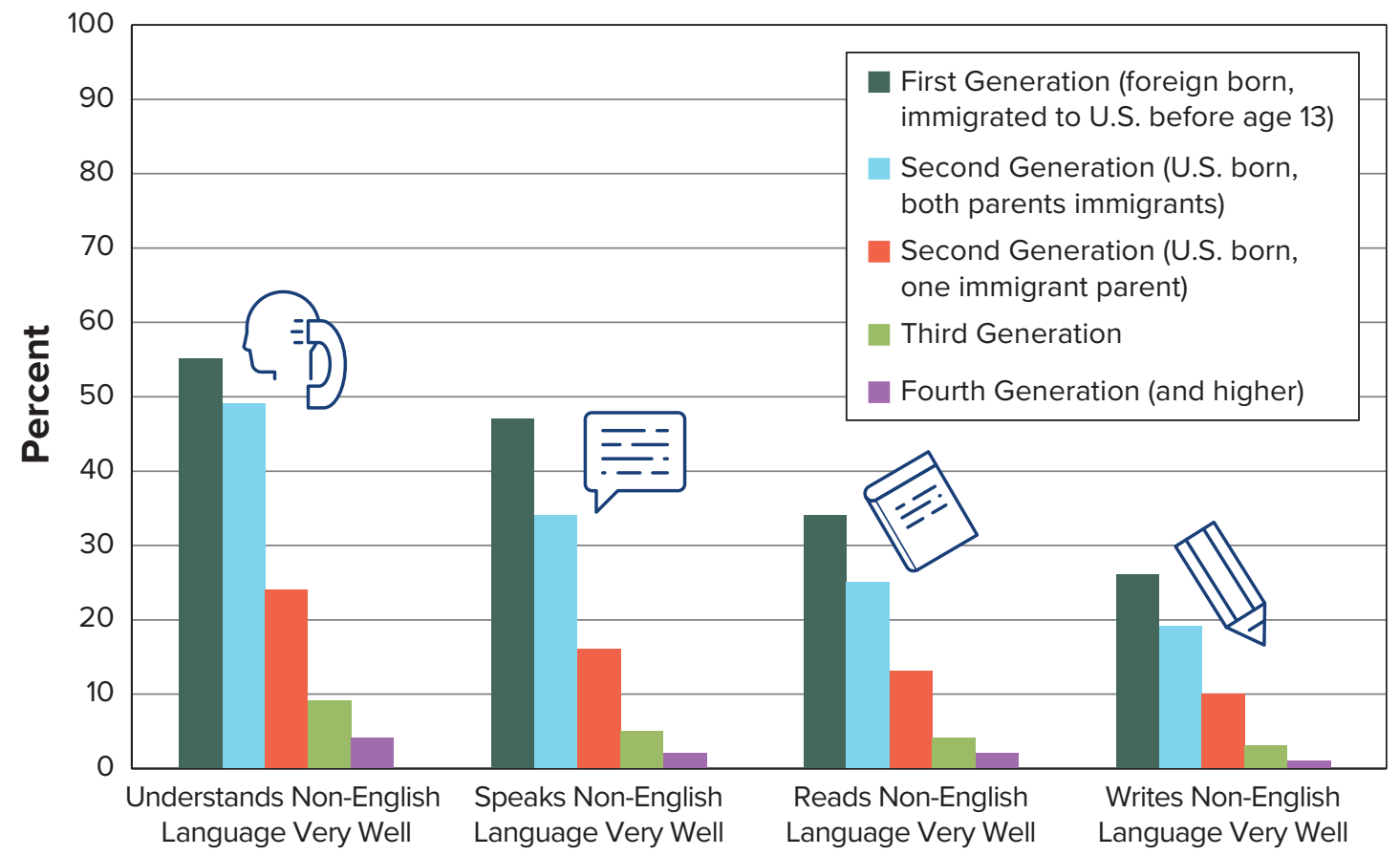

SOURCE: Alejandro Portes and Rubén G. Rumbaut, Children of Immigrants Longitudinal Study (CILS), 1991-2006, ICPSR20520.v2 (Ann Arbor, Mich.: Inter-University Consortium for Political and Social Research, 2012), http://doi.org/ 10.3886/ICPSR20520.v2; and Rubén G. Rumbaut, Frank D. Bean, Leo R. Chávez, et al., Immigration and Intergenerational Mobility in Metropolitan Los Angeles (IIMMLA), 2004, ICPSR22627.v1 (Ann Arbor, Mich.: Inter-University Consortium for Political and Social Research, 2008), http://doi.org/10.3886/ICPSR22627.v1. See also Rubén G. Rumbaut, "English Plus: Exploring the Socioeconomic Benefits of Bilingualism in Southern California," in The Bilingual Advantage: Language, Literacy and the U.S. Labor Market, ed. Rebecca M. Callahan and Patricia C. Gándara (Bristol, United Kingdom: Multilingual Matters, 2014). 
continue to be placed in English development programs based on the false assumption that their knowledge of a second language implies weak English skills, or that further education in a heritage language will hinder students' mastery of English. ${ }^{82}$ Occasionally, these decisions can be influenced by financial considerations, since some school districts receive funding when they assign more students to developmental English. In some cases, schools have not been required to inform parents that their children have been placed in such courses. These placements are problematic on several levels: They impede the education of otherwise qualified and capable students. They reinforce the mistaken idea that heritage languages are less valuable than other forms of knowledge. And they threaten the confidence and self-esteem of students who can and should excel within and beyond the classroom.
In place of such reflexive skepticism, individual students and communities would benefit greatly from a new respect for and investment in heritage language learning as an integral component of a broader national language strategy. ${ }^{83}$ While quality teaching resources already exist for many of the languages taught in U.S. schools, many more will need to be developed to support the great wealth of languages spoken in homes around the United States. The kind of public-private partnerships advocated in the previous section of this report will be crucial in these efforts as lesson plans, textbooks, and other media are developed to facilitate ongoing, lifelong instruction in heritage languages.

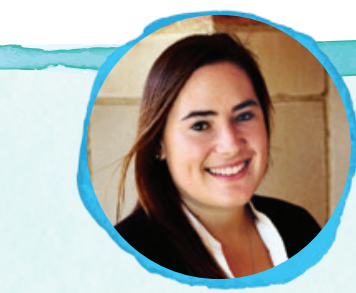

\section{Cosima Lenz}

Master of Public Health Candidate at UCLA Fielding School of Public Health

Cosima Lenz is a first-generation American whose family spoke German and English at home. She began learning Spanish as an elementary school student in California and continued to study the language throughout high school, before earning her bachelor's degree in German with a minor in public health from Northwestern University. Passionate about global health issues and aware of the serious challenges language barriers present to her chosen field, Lenz put her Spanish to use as a volunteer with the Somos Hermanos program-living in full cultural and linguistic immersion in Guatemala while teaching a weekly health class to local women and working at a rural clinic. Now pursuing a master of public health, she recently completed a research internship with the World Health Organization's Reproductive Health Research Department in Geneva, Switzerland, and has also participated in study abroad and research experiences in Germany and South Africa.

"Having foreign language skills in this day and age is critical due to the increasingly global world in which we live, and it's why I value my German and Spanish language skills. One of my goals in pursuing a career in public health is to use my Spanish and cross-cultural skills to improve quality and access to health care among the Latino community." 84 


\section{Native American Speakers}

Currently, the United States is home to over 450,000 speakers of Native American languages. Many of these American Indian, Alaska Native, Native Hawaiian, and Native American Pacific Islander languages are classified as endangered languages by UNESCO and other organizations supporting cultural preservation. Among languages indigenous to the North American continent (where language loss has been most severe), every Native American language other than Navajo has fewer than twenty thousand speakers and many are down to less than ten speakers. In the Native American Languages Act of 1990, Congress recognized the distinctive political status and cultural importance of all Native American languages and authorized programs to counter a historic "lack of clear, comprehensive, and consistent Federal policy," which has often "resulted in acts of suppression and extermination of Native American languages and culture." 85
Native North American languages are now the subject of intensive reclamation projects, including the Documenting Endangered Languages joint project of the National Endowment for the Humanities and the National Science Foundation. They are taught at tribal colleges and universities as well as at public universities in several states, including Alaska, Arizona, Hawaii, Minnesota, and Oklahoma. Alaska and Hawaii have also declared their Native American languages as official state languages.

Over the past twenty years, researchers have discovered that instruction in indigenous languages yields a variety of benefits for Native American children. It has been linked to improvements in:

- Academic achievement, retention rates, and school attendance;

- Local and national achievement test scores;

- Well-being, self-esteem, and self-efficacy; and

- Resiliency to addiction and the prevention of risky behaviors. ${ }^{86}$

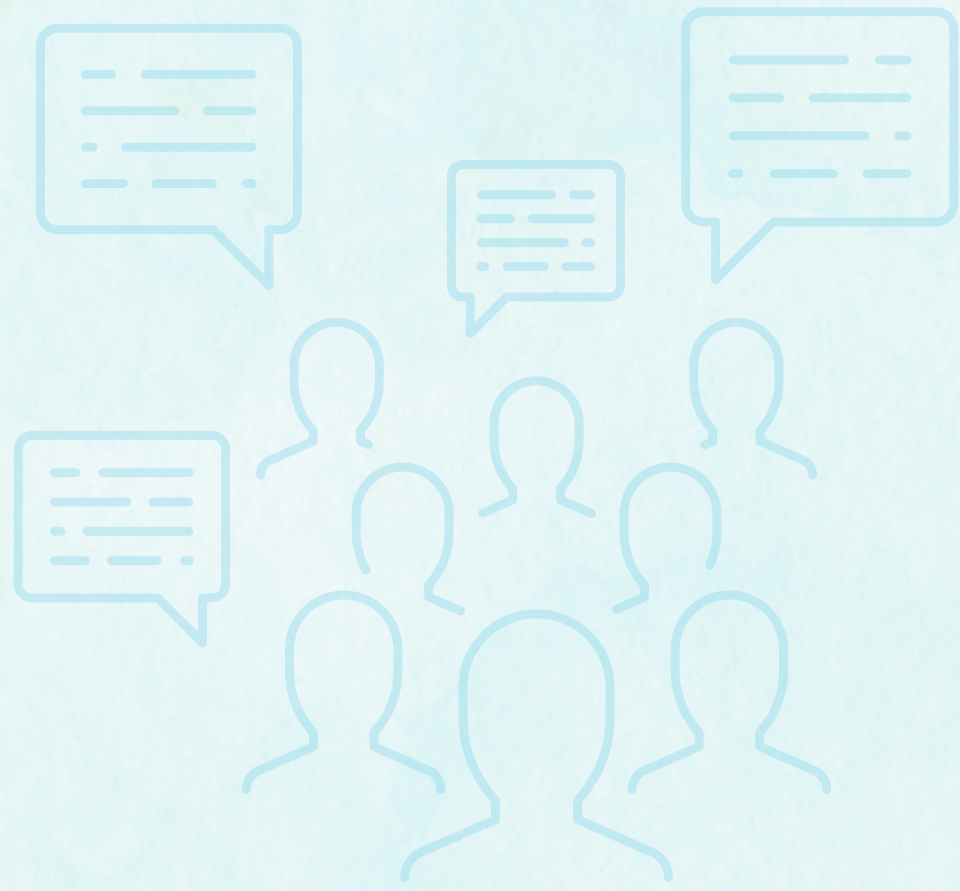




\section{Section 4: Encouraging International Study and Cultural Immersion}

A national strategy to broaden access to language education for every student in the United States, as preparation for life and work in a global twenty-first century, must also promote opportunities for students to travel, experience other cultures, and immerse themselves in languages as they are used in everyday interactions and across all segments of society.

In its Heart of the Matter report, the American Academy's Commission on the Humanities and Social Sciences wrote: "While foreign language study is a crucial step toward a more productive, reciprocal engagement with other cultures and governments, language study alone cannot provide the cultural and historical context in which such exchanges take place." For this reason, the Commission recommended that "transnational studies, study abroad, and international exchange programs should be expanded as part of undergraduate education." 87 According to the Institute for International Education, 313,00o students received credit for study abroad programs during the 2014-2015 academic year, and several education associations are calling for that number to double by the end of this decade. ${ }^{88}$ opportunities

for students to

travel, experience other

cultures, and immerse

themselves in languages as

they are used in everyday

interactions and across

all segments of society.
There are now many successful models for study abroad. For example, the Language Flagship model of the National Security Education Program (NSEP-DoD) prepares students at twenty-five American universities to speak, read, and listen in a non-English language at a professional level through intensive training at home and during an overseas capstone year. Similarly, the State Department's National Security Language Initiative for Youth (NSLI-Y) and Critical

\section{The Critical Language Scholarship Program}

According to the Critical Language Scholarship Program, an initiative of the U.S. Department of State, critical languages are non-Western European languages that are important to U.S. national security. ${ }^{89}$ As of December 2016 , the Department of State has identified fourteen critical languages and offers a variety of scholarships and programs for students who wish to study them. They are:
- Arabic
- Indonesian
Russian
- Azerbaijani
- Japanese
- Swahili
- Bangla
- Korean
- Turkish
Chinese
- Persian
- Urdu
- Hindi
- Punjabi

While many federal departments and agencies maintain lists of languages critical to their missions, such as the U.S. Army's Strategic Languages List, there is no single, unified list of languages considered critical to the federal government. 
Language Scholarship programs support over one thousand students of critical languages in overseas language study annually. Participants in these federal overseas programs come from all socioeconomic backgrounds and include students who have never before left the United States or studied the language in question. These programs prove that most students can successfully learn a language, given proper instruction and adequate support. $9^{\circ}$ The Departments of State and Defense should expand these successful immersion models, which are creating access for students to languages critical for U.S. national security and global competetiveness.

Many colleges and universities now offer opportunities for international study as well. However, these programs can be expensivein real dollars, in forfeited income during the period abroad, and in time spent away from home campuses and coursework-and are therefore less accessible to students from disadvantaged backgrounds. Campuses should make every effort to ensure that such students have access and support for overseas coursework-in part by recognizing overseas coursework for either elective or major credit. This recognition would enable students to apply financial aid and student loans to their time abroad, just as they apply it to their home campus studies. ${ }^{91}$ Unfortunately, even this recognition would not help students who wish to travel during the summer months (a more convenient time for many disadvantaged students) since, under current regulations, federal aid cannot be used to support summer study. The Department of Education should consider restructuring federal financial aid to help low-income undergraduates enjoy study abroad during the summer, as well as the academic year, to obtain language competence in their specific area of study.

\section{Jeffrey Wood}

Master of Arts Candidate at the Paul H. Nitze School of Advanced International Studies (SAIS) at The Johns Hopkins University; and 2016 Thomas R. Pickering Graduate Foreign Affairs Fellow

Jeffrey Wood was a Washington, D.C., public high school student when he had the opportunity to study abroad in China with D.C.-China Scholars-a program hosted by Americans Promoting Study Abroad-and was featured in the documentary film Beyond the Wall. He has since served as a student ambassador for the 100,000 Strong Foundation and Globalize D.C., and interviewed First Lady Michelle Obama live in China for Discovery Education. An alumnus of the National Security Language Initiative for Youth program, he has been granted numerous other awards, including a Gilman Scholarship, a Boren Undergraduate Scholarship, a UC Berkeley Public Policy and International Affairs Fellowship, and a Fulbright Teaching Fellowship. Wood holds a bachelor's degree in Chinese language and literature from George Mason University and a certificate in Chinese language and literature from Harbin Institute of Technology.

"Language has given me the ability to expand my understanding of my community, whether that's in my neighborhood or in a different country. Furthermore, language has given me a direct career path I didn't think was possible for me to achieve."92 
But academia and government are not the only potential partners in this effort. Indeed, American businesses may have the most to gain from a workforce that is competent in world languages and effective in international settings. Eighty-eight percent of the executives who responded to the 2014 Coalition for International Education sponsored study reported that international sales will be an equal or greater percentage of their business in the future, and almost two-thirds report a need for international skills at entry and management levels. ${ }^{93}$ In other words, the United States is rapidly approaching a significant skills gap. Many businesses recognize and address this need by providing language education for their employees through a variety of means, including internal training programs and sponsored coursework. Community colleges have also become important partners by providing effective and affordable language instruction for adults. In addition, through sponsored internships, the private sector and many NGOs have discovered ways to develop a multilingual workforce that can meet their future needs. Some work through programs like Northeastern University's Global Co-op, which connects students with professional internships abroad, thereby offering language and cultural training as well as valuable work experience. ${ }^{94}$ Even a quick online search reveals dozens of such opportunities for students interested in exploring professional experiences abroad, including programs with Deloitte, Goldman-Sachs, and the World Bank, as well as U.S. embassies, world governments, and a host of other large and small corporate and nonprofit entities. ${ }^{95}$ Clearly, it is in the best interests of these organizations, and of U.S business more generally,

\section{World-Readiness Standards}

A number of teacher associations and learned societies have collaborated to create a series of standards to help design curricula and establish performance outcomes for students as well as for language programs. The primary goal areas of the standards are designed to encourage students achieving the " 5 Cs":

- Communication: Communicate effectively in more than one language in order to function in a variety of situations and for multiple purposes.

- Cultures: Interact with cultural competence and understanding.

- Connections: Connect with other disciplines and acquire information and diverse perspectives in order to use the language to function in academic and career-related situations.

- Comparisons: Develop insight into the nature of language and culture in order to interact with cultural competence.

- Communities: Communicate and interact with cultural competence in order to participate in multilingual communities at home and around the world.

Since 2013 , forty states have adopted the World-Readiness Standards as part of their language education programs. ${ }^{96}$

to recruit and train more talented young people for success in a global economy-and international internships should be a part of any global strategy. 


\section{Conclusion}

Language acquisition on the scale that this Commission proposes will require a combination of skillful instruction, technical assistance and innovation, new and redirected investments, public-private partnerships, and the personal commitment of each individual language learner.

In the past, the United States has only focused on language education in times of great need, such as encouraging Russian studies during the
Cold War or instruction in certain Middle Eastern languages after the terrorist attacks of 2001. At such moments, enrollments increase dramatically, but students require years of training before they can achieve a useful level of proficiency, often long after the immediate crisis has faded and national priorities have changed.

A wiser, more forward-thinking strategy would be to steadily improve access to as many lan-

\section{Postsecondary Enrollments in the Most Commonly Taken "Critical Need" Language Courses, 1965-2013}

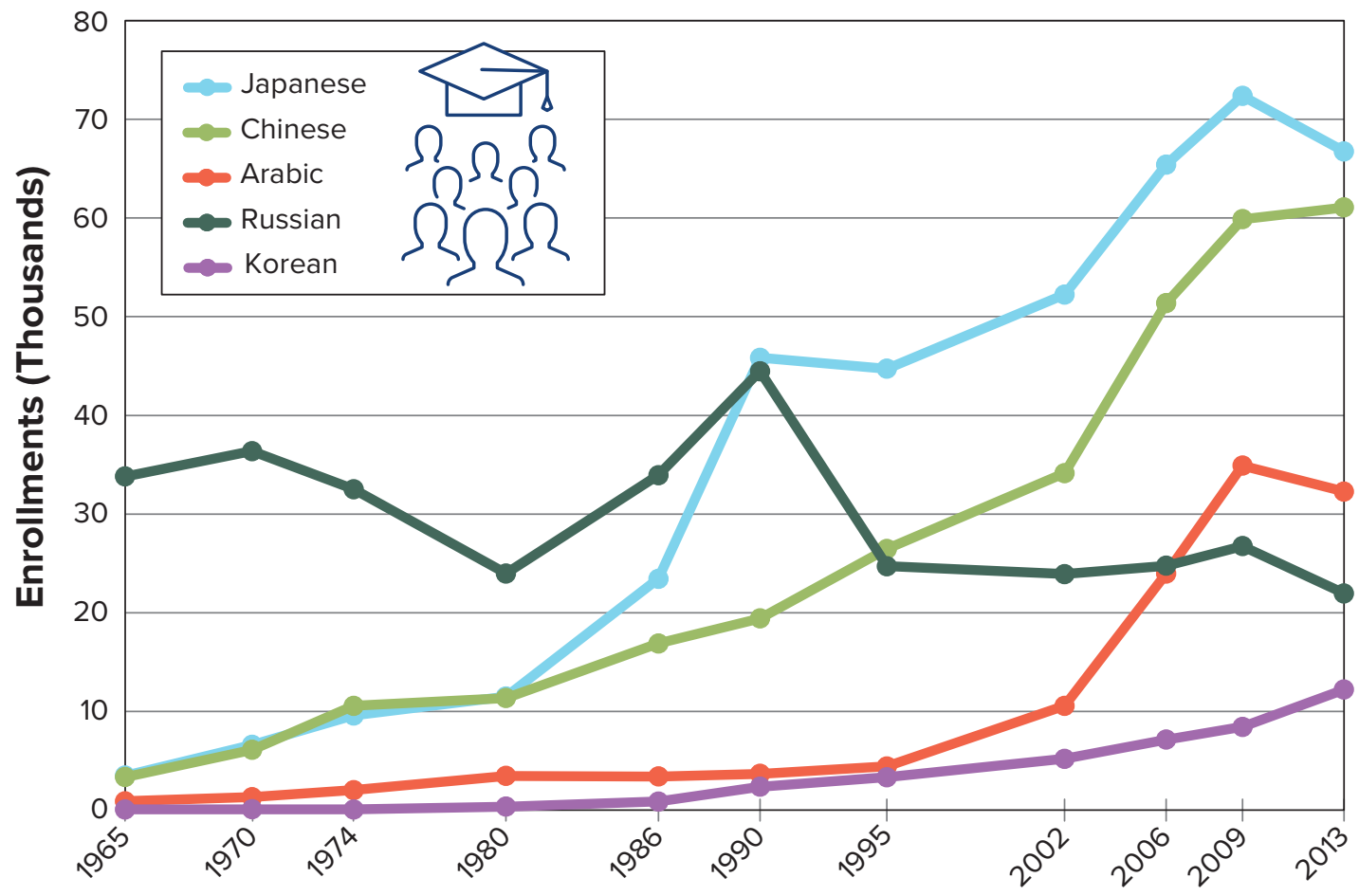

SOURCE: Humanities Indicators analysis of data in Modern Language Association, Language Enrollment Database, https://apps.mla.org/flsurvey_search (accessed March 28, 2016). Tabulation excludes enrollments in American Sign Language, which had the third-largest number of enrollments among languages other than English. 
guages as possible for people of every age, ethnicity, and socioeconomic backgroundto treat language education as a persistent national need like competency in math or English, and to ensure that a useful level of proficiency is within every student's reach. That is why this report has focused on five capacitybuilding goals:
- Provide targeted programming and additional support for Native American languages being used as primary languages of education.

- Promote opportunities for students to learn languages by experiencing other cultures and immersing themselves in languages as they are used in everyday interactions and across all segments of society.
Increase the number of language teachers at all levels of education so that every child in every state has an opportunity to learn a language other than English.

- Supplement language instruction across the education system through publicprivate partnerships among schools, government, philanthropies, businesses, and local community members.

Support heritage languages already spoken in communities across the nation, and help these languages persist from one generation to the next.
Improve access to as many languages as possible for people of every age, ethnicity, and socioeconomic background.

Taken together, these goals are aimed at building a strong world language capability alongside English. Each goal can be addressed in a variety of ways. Throughout this report, the Commission has offered examples, successful models, and best practices in order to encourage more innovation around the country. Ultimately, it is up to all of us-parents, students, educators, policy-makers, and businesses-to make language learning a valued national priority, and to address a need that is more acute today than at any other time in our history. 


\section{Endnotes}

1. Advancing Knowledge: Selections from the Archives of the American Academy of Arts and Sciences (Cambridge, Mass.: American Academy of Arts and Sciences, 2015).

2. U.S. Census Bureau, "Detailed Languages Spoken at Home and Ability to Speak English for the Population 5 Years and Over for United States: 2009-2013," American Community Survey, October 2015, http://www.census .gov/data/tables/2013/demo/2009-2013-lang-tables.html.

3. The Native American Languages Act of 1990 is the governing statute for the distinctive Native American language provisions of the Every Student Succeeds Act (ESSA) and the primary policy statute of the federal government that provides the basis for distinctive political recognition and support for Native American languages. Native American languages are defined by the NALA as American Indian, Native Alaskan, Native Hawaiian, and Native American Pacific Island languages.

4. See, for example, Brian T. Edwards, "Teach Arabic in Public Schools," Chicago Tribune, April 6, 2015, http://www.chicagotribune.com/news/opinion/commentary/ct-arabic-language-public-schools-perspec-0406 -20150403-story.html.

5. Rick Noack and Lazaro Gamio, "The World's Languages, in 7 Maps and Charts," The Washington Post, April 23, 2015, https:/www.washingtonpost.com/news/worldviews/wp/2015/04/23/the-worlds-languages-in-7-maps -and-charts/.

6. U.S. Census Bureau, "Detailed Languages Spoken at Home and Ability to Speak English for the Population 5 Years and Over for United States: 2009-2013."

7. "2014 U.S. Business Needs for Employees with International Expertise," Shirley J. Daniel and Fujiao Xie, Center for International Business Education and Research at University of Hawai'i at Manoa, and Ben L. Kedia, Center for International Business Education and Research at the University of Memphis. A collaboration of the Coalition for International Education and the Association for International Business Education and Research for Internationalization of U.S. Education in the 21st Century, April 2014, William \& Mary, Williamsburg, VA. http:// www.wm.edu/offices/revescenter/globalengagement/internationalization/papers\%20and\%20presentations/ danielkediafull.pdf.

8. Office of Public Affairs, U.S. Department of Commerce, "U.S. Commerce Department Releases New Report on Foreign Direct Investment Trends," press release, June 20, 2016, https://www.commerce.gov/news/press -releases/2016/06/us-commerce-department-releases-new-report-foreign-direct-investment; and Joint $\mathrm{Na}$ tional Committee for Languages, The Contributions of Language to the Economic Interests of the United States (Cambridge, Mass.: American Academy of Arts and Sciences, 2015), https://www.amacad.org/multimedia/pdfs/ TheContributionsofLanguagetotheEconomicInterestsoftheUnitedStates.pdf.

9. Global Cities Initiative, Metro Atlanta: Foreign Direct Investment Plan (Washington, D.C.: Brookings Institution and J. P. Morgan Chase, 2016), http://www.atlantafdiportal.com/wp-content/uploads/2016/05/16-57-FDI -FINAL_WEB-2.pdf; and Rebecca M. Callahan and Patricia C. Gándara, eds., The Bilingual Advantage: Language, Literacy and the U.S. Labor Market (Bristol, United Kingdom: Multilingual Matters, 2014), 178.

10. David Cyranoski, "Bird Flu Data Languish in Chinese Journals: Health Authorities in the Dark as Warnings Go Untranslated," Nature 430 (955) (August 2004), http://www.nature.com/nature/journal/v430/n7003/ full/430955a.html.

11. U.S. Congress, America COMPETES Act, August 9, 2007, 110th Congress, Public Law 110-69, 94, https:// www.congress.gov/110/plaws/publ69/PLAW-110publ69.pdf.

12. Ibid. 
13. Email exchange with the Commission on Language Learning, January 2017.

14. U.S. Senate, Committee on Homeland Security and Governmental Affairs, A National Security Crisis: Foreign Language Capabilities in the Federal Government, 112th Congress, 2nd Sess., May 21, 2012, S. Hrg. 112-663, 9, http://www.gpo.gov/fdsys/pkg/CHRG-112shrg75214/pdf/CHRG-112shrg75214.pdf.

15. Laura J. Junor, "A National Security Crisis: Foreign Language Capabilities in the Federal Government," statement before the Committee on Homeland Security and Governmental Affairs, Subcommittee on Oversight of Government Management, Federal Workforce, and the District of Columbia, United States Senate, May 21, 2012, 3.

16. U.S. Senate, Committee on Homeland Security and Governmental Affairs, A National Security Crisis: Foreign Language Capabilities in the Federal Government.

17. For more information on languages and national security, see Gail H. McGinn, Foreign Language, Cultural Diplomacy, and Global Security (Cambridge, Mass.: American Academy of Arts and Sciences, 2015), https:// www.amacad.org/multimedia/pdfs/Foreign-language-Cultural-Diplomacy-Global-Security.pdf.

18. Executive Order 13166 of August 11, 2000, "Improving Access to Services for Persons with Limited English Proficiency," Code of Federal Regulations, Title 3 (Washington, D.C.: U.S. Government Publishing Office, 2001), 289-291.

19. See Camille Ryan, Language Use in the United States: 2011, American Community Survey Reports (Washington, D.C.: U.S. Census Bureau, August 2013), http://www.census.gov/prod/2013pubs/acs-22.pdf; Executive Order 13166 of August 11, 2000; and U.S. Congress, Patient Protection and Affordable Care Act, March 23, 2010, 111th Congress, 2nd Sess., H.R. 3590.

20. Terrence Wiley, Beatriz Arias, Jennifer Renn, and Shereen Bhalla, Language and the Fulfillment of the Potential of All Americans (Cambridge, Mass.: American Academy of Arts and Sciences and the Center for Applied Linguistics, 2015), 20, https://www.amacad.org/multimedia/pdfs/CAL-AAASWhitePaper-LanguagePotential Americans.pdf.

21. Laura K. Abel, Language Access in the Federal Courts (New York: National Center for Access to Justice at Cardozo School of Law, 2013), http://ncforaj.org/wp-content/uploads/2013/12/abel-ncaj-language-access-federal -courts.pdf.

22. Rubén G. Rumbaut and Douglas S. Massey, "Immigration \& Language Diversity in the United States," Doedalus 142 (3) (Summer 2013): 141.

23. U.S. Census Bureau, "Census Bureau Reports at Least 350 Languages Spoken in U.S. Homes," press release CB15-185, November 3, 2015, http://www.census.gov/newsroom/press-releases/2015/cb15-185.html.

24. Penelope W. Armstrong and Jerry D. Rogers, "Basic Skills Revisited: The Effects of Foreign Language Instruction on Reading, Math, and Language Arts," Learning Languages 2 (3) (1997): 20-31.

25. Samantha A. Fan, Zoe Liberman, Boaz Keysar, et al., "The Exposure Advantage: Early Exposure to Multilingual Environment Promotes Effective Communication," Psychological Science 26 (7) (2015), http://pss.sagepub .com/content/early/2015/05/08/0956797615574699.abstract.

26. Email exchange with the Commission on Language Learning, November 2016.

27. Clara Moskowitz, "Learning a Second Language Protects Against Alzheimer's," Live Science, February 18, 2011, http://www.livescience.com/12917-learning-language-bilingual-protects-alzheimers.html. 
28. Richard D. Brecht, America's Languages: Challenges and Promise (Cambridge, Mass.: American Academy of Arts and Sciences, 2015), https://www.amacad.org/multimedia/pdfs/AmericasLanguagesChallengesand Promise.pdf.

29. "Foreign Language Skills Statistics," Eurostat Statistics Explained, http://ec.europa.eu/eurostat/statistics -explained/index.php/Foreign_language_skills_statistics.

30. U.S. Census Bureau, "Detailed Languages Spoken at Home and Ability to Speak English for the Population 5 Years and Over for United States: 2009-2013."

31. Bethany Allen-Ebrahimian, "Can 1 Million American Students Learn Mandarin?” Foreign Policy, September 25, 2015, http://foreignpolicy.com/2015/09/25/china-us-obamas-one-million-students-chinese-language -mandarin/.

32. American Academy of Arts and Sciences, The State of Languages in the U.S.: A Statistical Portrait (Cambridge, Mass.: American Academy of Arts and Sciences, 2016), 11.

33. Ibid., 9. This is in stark contrast to the 84 percent of $\mathrm{K}-8$ students in the twenty-eight member nations of the European Union who have studied a second language. See Eurostats, "Foreign Language Learning Statistics," September 2016, http://ec.europa.eu/eurostat/documents/2995521/7662394/3-23092016-AP-EN.pdf/ 57d3442c-7250-4aae-8844-c2130eba8e0e.

34. U.S. Department of Education, Office of Postsecondary Education, Teacher Shortage Areas, Nationwide Listing, 1990-1991 through 2016-2017 (Washington, D.C.: U.S. Department of Education, 2016), http://www2.ed.gov/ about/offices/list/ope/pol/tsa.pdf.

35. Liz Bowie, "In Baltimore Area Schools, Young Students are Learning a Foreign Language," The Baltimore Sun, December 2, 2014, http://www.baltimoresun.com/news/maryland/education/bs-md-foreign-language -20141201-story.html\#page $=1$.

36. Julia Morales, Alejandra Calvo, and Ellen Bialystok, "Working Memory Development in Monolingual and Bilingual Children," Journal of Experimental Child Psychology 114 (2) (2013), https://www.ncbi.nlm.nih.gov/ pubmed/23059128.

37. Utah State Office of Education, Critical Languages: Dual Language Immersion Education Appropriations Report (Salt Lake City: Utah State Board of Education, 2013), http://www.schools.utah.gov/legislativematerials/ 2013/Critical_Language_Dual_Immersion_Legislative_Repor.aspx.

38. Ellen Bialystok, "Components of Executive Control with Advantages for Bilingual Children in Two Cultures," Cognition 112 (3) (2009), http://www.sciencedirect.com/science/article/pii/S0010027709001577.

39. Samantha P. Fan, Zoe Libermen, Boaz Keysar, and Katherine D. Kinzler, "The Exposure Advantage: Early Exposure to a Multilingual Environment Promotes Effective Communication," Psychological Science 26 (7) (2015): 1090-1097.

40. Ellen Bialystok, "Bilingualism as a Protection Against the Onset of Symptoms of Dementia," Neuropsychologia 45 (2) (2007), http://www.sciencedirect.com/science/article/pii/S0028393206004076; and Moskowitz, "Learning a Second Language Protects Against Alzheimer's."

41. For more on the cognitive benefits of language learning, see Judith F. Kroll and Paola E. Dussias, Language and Productivity for All Americans (Cambridge, Mass.: American Academy of Arts and Sciences, 2016), http:// www.amacad.org/multimedia/pdfs/KrollDussias_April\%205.pdf. 
42. Corey Mitchell, "Need for Bilingual Educators Moves School Recruitment Abroad," Education Week, January 25, 2016, http://www.edweek.org/ew/articles/2016/01/27/need-for-bilingual-educators-moves-school -recruitment.html.

43. Carola McGiffert, "Introducing Our 1 Million Strong Implementation Partners," U.S. China Strong, http:// uschinastrong.org/2016/09/25/introducing-1-million-strong-implementation-partners/.

44. Tim Henderson, "Why American Schools Are Starting to Recruit More Teachers from Foreign Countries," The Huffington Post, October 13, 2015, http://www.huffingtonpost.com/2015/10/13/schools-recruit-foreign -teachers_n_8287694.html.

45. For further information on the federal civil rights framework for the provision of programs to English Learners, see U.S. Department of Justice and U.S. Department of Education, "Dear Colleague Letter, English Learner Students and Limited English Proficient Parents," January 7, 2015, https://www2.ed.gov/about/offices/ list/ocr/letters/colleague-el-201501.pdf.

46. Utah Immersion, “Why Immersion?” http://utahdli.org/whyimmersion.html.

47. Utah State Office of Education, Critical Languages: Dual Language Immersion Education Appropriations Report, http://www.schools.utah.gov/legislativematerials/2013/Critical_Language_Dual_Immersion_Legislative _Repor.aspx.

48. For an overview, see U.S. Department of Education, Office of English Language Acquisition, "Dual Language Education Programs: Current State Policies and Practices," https://ncela.ed.gov/files/rcd/TO20 _DualLanguageRpt_508.pdf.

49. Jazmine Ulloa, "California Will Bring Back Bilingual Education as Proposition 58 Cruises to Victory," Los Angeles Times, November 8, 2016, http://www.latimes.com/nation/politics/trailguide/la-na-election-day -2016-proposition-58-bilingual-1478220414-htmlstory.html.

50. NYC Department of Education, “Chancellor Fariña Announces 38 New Bilingual Programs," April 4, 2016, http://schools.nyc.gov/Offices/mediarelations/NewsandSpeeches/2015-2016/Chancellor+Farina+Announces $+38+$ New+Bilingual+Programs.htm.

51. RAND Corporation, American Councils for International Education, and Portland Public Schools, "Study of Dual Language Immersion in the Portland Public Schools: Year 4 Briefing," November 2015, http://www.pps .net/cms/lib8/OR01913224/Centricity/Domain/85/DLI_Year_4_Summary_Nov2015v7.pdf. See also Jennifer L. Steele, Robert O. Slater, Gema Zamarro, et al., "The Effects of Dual Language Immersion Programs on Student Achievement: Evidence from Lottery Data," American Educational Research Journal (Centennial Issue) 53 (5) (forthcoming).

52. Swarthmore College, "State-by-State Chart for Policies on Reciprocity and Out-of-State Teacher Certification," http://www.swarthmore.edu/Documents/State\%20Certification\%20Reciprocity.pdf (accessed December 12, 2016).

53. Federal Student Aid, U.S. Department of Education, https://studentaid.ed.gov/sa/ (accessed January 19, 2017).

54. ACE/CIE, Engaging the World: U.S. Global Competence for the 21st Century, "Global Competence Video: Dana Banks," http://www.usglobalcompetence.org/videos/banks_large.html.

55. Lisa W. Foderaro, "Budget-Cutting Colleges Bid Some Languages Adieu," The New York Times, December 3, 2010, http://www.nytimes.com/2010/12/05/education/05languages.html. 
56. Big Ten Academic Alliance, "Introduction," https://www.btaa.org/projects/shared-courses/courseshare/ introduction.

57. Five College Consortium, "Five College Center for the Study of World Languages," https://www.fivecolleges .edu/fclang.

58. Association of Independent Colleges \& Universities of Rhode Island, "Academic Programs: Language Consortium Program," http://aicuri.org/initiatives/academic/.

59. North Carolina State University, "NC State Language Exchange," https://fll.chass.ncsu.edu/undergraduate/ language_exchange.php.

60. Yale Center for Language Study, "Shared Course Initiative," http://cls.yale.edu/shared-course-initiative (accessed January 27, 2017).

61. National Coalition of Native American Language Schools and Programs, http://www.ncnalsp.org/ about-the-coalition/.

62. Recent surveys of state and local job markets reveal a significant increase in the number of job postings that list language skills as a requirement. See American Academy of Arts and Sciences, The State of Languages in the U.S.: A Statistical Portrait, 17.

63. Colleen Flaherty, "More Than Words," Inside Higher Ed, November 2, 2016, https://www.insidehighered .com/news/2016/11/02/princeton-proposal-would-require-all-students-even-those-already-proficient-study.

64. 'Aha Pūnana Leo, “A Timeline of Revitalization," http://www.ahapunanaleo.org/index.php?/about/a_timeline _of_revitalization/ (accessed January 27, 2017); and Karen Lee and Jean Osumi, "Native Hawaiian Student Outcomes," presentation at the Native Hawaiian Education Council Meeting, Honolulu, Hawaii, November 2016.

65. One Fulbright-Hayes Program, Group Projects Abroad-Advanced Language Training, is designed specifically to provide intensive language training for U.S. graduate and undergraduate students.

66. Office of Science and Technology Policy, Executive Office of the President, Report from the Interagency Working Group on Language \& Communication (Washington, D.C.: Executive Office of the President of the United States, 2016), 14, https://www.whitehouse.gov/sites/default/files/microsites/ostp/NSTC/report_of_the _interagency_working_group_on_language_and_communication_final.pdf (accessed on January 19, 2017); and U.S. Department of Education, Higher Education: Fiscal Year 2017 Budget Request (Washington, D.C.: U.S. Department of Education, 2016), https://www2.ed.gov/about/overview/budget/budget17/justifications/r-highered.pdf.

67. Center for Arabic Language and Culture, "Welcome to CALC," http://www.calcchicago.org/home.html.

68. FACE Foundation, "French Heritage Language Program," http://face-foundation.org/french-heritage -language-program/.

69. Humanities Nebraska, "Prime Time Family Reading Time," http://humanitiesnebraska.org/program/prime -time-family-reading-time/.

70. Alaska Native Languages, "Yugtun/Cugtun (Yup'ik/Cup'ik/Cup’ig Language)," http://www.alaskanative languages.org/centralalaskanyupik.

71. Louis Karno and Company Communications, "NH Humanities Council Celebrates Publication of EnglishNepali Picture Book with a Public Folktale Festival on August 17," The Tip Sheet, July 30, 2012, http:// thetipsheet.typepad.com/the_tip_sheet/2012/07/nh-humanities-council-celebrates-publication-of-english -nepali-picture-book-with-a-public-folktale-festival-on-august-17.html. 
72. Global Cities Initiative, Metro Atlanta.

73. John M. Grandin, “International Engineering Education: What Difference Does It Make?” Online Journal for Global Engineering Education 6 (1) (2012), 2, http://digitalcommons.uri.edu/ojgee/vol6/iss1/7.

74. U.S. Census Bureau, "Detailed Languages Spoken at Home and Ability to Speak English for the Population 5 Years and Over for United States: 2009-2013."

75. Alejandro Portes and Rubén G. Rumbaut, Children of Immigrants Longitudinal Study (CILS), 1991-2006, ICPSR20520.v2 (Ann Arbor, Mich.: Inter-University Consortium for Political and Social Research, 2012), http:// doi.org/10.3886/ICPSR20520.v2; and Rubén Rumbaut, Frank D. Bean, Leo R. Chávez, et al., Immigration and Intergenerational Mobility in Metropolitan Los Angeles (IIMMLA), 2004, ICPSR22627.v1 (Ann Arbor, Mich.: Inter-University Consortium for Political and Social Research, 2008), http://doi.org/10.3886/ICPSR22627.v1. See also Rubén G. Rumbaut, "English Plus: Exploring the Socioeconomic Benefits of Bilingualism in Southern California," in The Bilingual Advantage: Language, Literacy and the U.S. Labor Market, ed. Callahan and Gándara.

76. Sealaska Heritage, "Education Programs," http://www.sealaskaheritage.org/institute/education/programs.

77. Maine French Heritage Language Program, "About," http://www.mfhlp.com/about.html.

78. Center for Applied Linguistics, "Heritage Langue Programs-Spanish: Beardstown CUSD \#15 Dual Language Enrichment Program,” http://www.cal.org/heritage/profiles/programs/Spanish_K-12_Beardstown.html.

79. University of Houston, "Heritage Track," http://www.uh.edu/class/spanish/language-programs/heritage -language/index.php.

80. University of Washington, "Heritage Language Courses," https://spanport.washington.edu/heritage-language -courses; University of Arizona, "Spanish as a Heritage Language," http://spanish.arizona.edu/undergrad/ spanish-heritage-language; and University of Oregon, "Spanish Heritage Language Program (SHL)," http:// rl.uoregon.edu/undergraduate/shl/.

81. Columbia University, “Undergraduate Courses: Russian Language (RUSS)," http://slavic.columbia.edu/ search/node/heritage\%20Russian.

82. Recent studies suggest that strong skills in a heritage language actually help to promote efficient learning in English. See Karen Thompson, "English Learners' Time to Reclassification: An Analysis," Educational Policy (2015).

83. All students, including English speakers, would benefit from a more inclusive and integrative approach to the education of English Language Learners (ELLs). Some schools in Virginia are already experimenting with new "whole school" programs for teaching ELLs, in which every student prepares for mainstream content classes (in science, math, history, and so on) by first participating in in-depth sessions on vocabulary, reading, and writing in English. These programs reduce the time that ELLs spend away from their English-speaking peers and introduce a new educational rigor that has proven helpful to English speakers as well. Early research suggests that this is a path worth pursuing in more districts around the country. Margarita Calderón, "A Whole-School Approach to English Learners," Educational Leadership 73 (5) (February 2016), http://www.ascd.org/publications/ educational_leadership/feb16/vol73/num05/A_Whole-School_Approach_to_English_Learners.aspx.

84. Email exchanges with the Commission on Language Learning, December 2015 and November 2016.

85. Julie Siebens and Tiffany Julian, "Native North American Languages Spoken at Home in the United States and Puerto Rico: 2006-2010," American Community Survey Briefs, December 2011, https://www.census.gov/ prod/2011pubs/acsbr10-10.pdf; and U.S. Senate, S.2167-Native American Languages Act, October 30, 1990, Public Law No. 101-477, https://www.congress.gov/bill/101st-congress/senate-bill/2167/text. 
86. Joana Jansen, Lindsay Marean, and Janne Underriner, Benefits of Indigenous Language Learning (Eugene: University of Oregon, 2012), http://pages.uoregon.edu/nwili/wp-content/uploads/2012/07/forwebpageBenefitsL2 _ECE10_17_14.pdf; and National Endowment for the Humanities, "Documenting Endangered Languages," https://www.neh.gov/grants/preservation/documenting-endangered-languages.

87. American Academy of Arts and Sciences, The Heart of the Matter: The Humanities and Social Sciences for a Vibrant, Competitive, and Secure Nation (Cambridge, Mass.: American Academy of Arts and Sciences, 2013), 58-59.

88. Institute of International Education, "Open Doors," http://www.iie.org/Research-and-Publications/Open -Doors\#.WDyYPPkrKUk; and Institute of International Education, "Generation Study Abroad," http://www .iie.org/Programs/Generation-Study-Abroad\#.WDyYq_krKUk.

89. The Critical Language Scholarship Program, http://clscholarship.org/.

90. Dan E. Davidson, "The Development of L2 Proficiency and Literacy within the Context of the Federally Supported Overseas Language Training Programs for Americans," To Advanced Proficiency and Beyond: Theory and Methods for Developing Superior Second-Language Ability, ed. Tony Brown and Jennifer Brown (Washington, D.C.: Georgetown University Press, 2015), 117-150.

91. Federal student aid can be used for study abroad (short-term programs while remaining enrolled at a U.S. home campus) and for direct enrollment at a foreign higher education institution (HEI) if the foreign HEI has been approved for federal student aid participation. See Federal Student Aid, U.S. Department of Education, "International Schools," https://studentaid.ed.gov/sa/prepare-for-college/choosing-schools/types/international (accessed January 19, 2017).

92. Email exchange with the Commission on Language Learning, November 2016.

93. Daniel, Xie and Kedia, "2014 U.S. Business Needs for Employees with International Expertise."

94. Northeastern University, Global Experience Office, "Global Co-Op," http://www.northeastern.edu/geo/ globalcoop/.

95. Go Overseas, “10 Paid Internships Abroad in Summer 2016 \& 2017," https://www.gooverseas.com/blog/ 10-paid-internships-abroad-in-summer.

96. American Council on the Teaching of Foreign Languages, "World-Readiness Standards for Learning Languages," https://www.actfl.org/publications/all/world-readiness-standards-learning-languages. 


\title{
Lhnited States Senate
}

WASHINGTON, DC 20510

November 20, 2014

\author{
Dr. Don M. Randel \\ Chair of the Board \\ American Academy of Arts and Sciences \\ Norton's Woods \\ 136 Irving Street \\ Cambridge, MA 02138 \\ Dr. Jonathan F. Fanton \\ President \\ American Academy of Arts and Sciences \\ Norton's Woods \\ 136 Irving Street \\ Cambridge, MA 02138
}

Dear Dr. Randel and Dr. Fanton:

We write to request that the American Academy undertake a new study, proceeding from the excellent work presented in the Heart of the Matter, to examine the nation's current capacity in languages, how a greater attention to language training can improve the education of a citizenry prepared to thrive in a multicultural society and a global economy, and how such preparation influences international cooperation and diplomacy, trade and foreign investment, national security, and the ability of all Americans to enjoy a rich and meaningful life.

English is no longer sufficient as a lingua franca-neither at home nor abroad. The percentage of the world's population that speaks English as a first language is declining rapidly; if current demographic trends continue, only $5 \%$ will be native English speakers by 2050 . At the same time, the ability to communicate in languages other than English has never been more important, as:

- American jobs and exports are more dependent than ever on foreign markets;

- The American population is increasingly multilingual;

- Americans are more engaged diplomatically and militarily around the globe than ever before; and

- Challenges like poverty and disease, and opportunities in scientific research and technological innovation, all require greater international understanding and cooperation.

The American Academy of Arts \& Sciences has the ability to provide critical assistance in this effort by assembling education, business, and policy leaders to examine the relationship between language learning and the nation's strength, competitiveness, and well-being. 
CONGRESSIONAL LETTERS

In order to assess the national impact of language learning, we request that the American Academy examine the following questions:

How does language learning influence economic growth, cultural diplomacy, the productivity of future generations, and the fulfillment of all Americans? What actions should the nation take to ensure excellence in all languages as well as international education and research, including how we may more effectively use current resources to advance language learning?

Your answers to these questions will help Congress, the states, and local communities design effective programs to ensure that America remains competitive and strong. We look forward to reviewing the results of your efforts.

Sincerely,
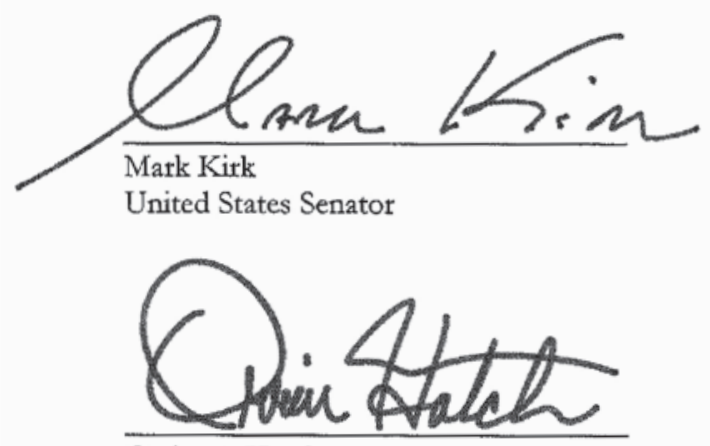

Orrin G. Hatch

United States Senator

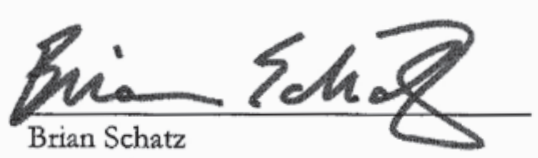

United States Senator:

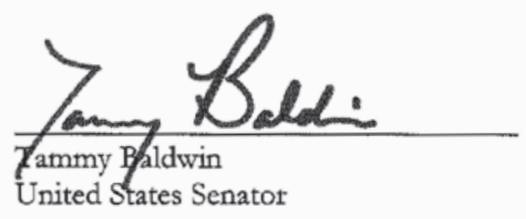

40

Commission on Language Learning 


\section{Congress of the Anited States

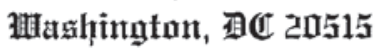

November 21, 2014

Dr. Don M. Randel

Chair of the Board

American Academy of Arts \& Sciences

Norton's Woods

136 Irving Street

Cambridge, MA 02138

Dr. Jonathan Fanton

President

American Academy of Arts \& Sciences

Norton's Woods

136 Irving Street

Cambridge, MA 02138

Dear Dr. Randel and Dr. Fanton:

We write to request that the American Academy undertake a new study, proceeding from the excellent work presented in The Heart of the Matter, to examine the nation's current capacity in languages, and how a greater attention to language training can improve the education of a citizenry prepared to thrive in a multicultural society participating in a global economy and how such preparation influences international cooperation and diplomacy, trade and foreign investment, national security and the ability of all Americans to enjoy a rich and meaningful life.

English is no longer sufficient as a lingua franca - neither at home or abroad. The percentage of the world's population that speaks English as a first language is declining rapidly; if current demographic trends continue, only $5 \%$ will be native English speakers by 2050 . At the same time, the ability to communicate in languages other than English has never been more important, as:

- American jobs and exports are more dependent than ever on foreign markets;

- The American population is increasingly multilingual;

- Americans are more engaged diplomatically and militarily around the globe than ever before; and

- Challenges like poverty and disease, and opportunities in scientific research and technological innovation, all require greater international understanding and cooperation.

The American Academy of Arts \& Sciences has the ability to provide critical assistance in this effort by assembling education, business and policy leaders to examine the relationship between language learning and the nation's strength, competitiveness and well-being. 
In order to assess the national impact of language learning, we request that the American Academy examine the following questions:

How does language learning influence economic growth, cultural diplomacy, the productivity of future generations, and the fulfillment of all Americans? What actions should the nation take to ensure excellence in all languages as well as international education and research, including how we may more effectively use current resources to advance language attainment?

Your answers to these questions will help Congress, the states and local communities design effective programs to ensure that America remains competitive and strong. We look forward to reviewing the results of your efforts.

Sincerely,

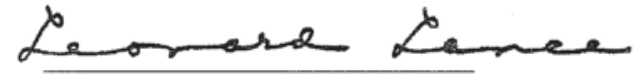

Leonard Lance

Member of Congress

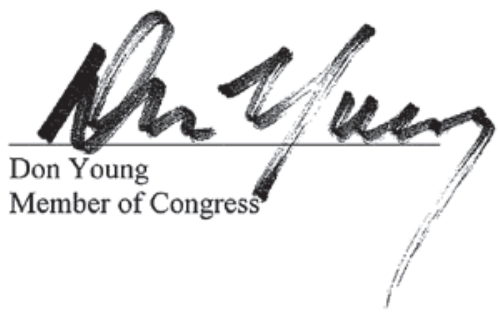

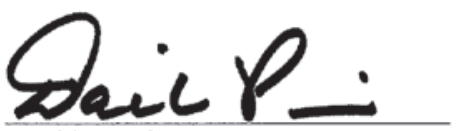

David E. Price

Member of Congress

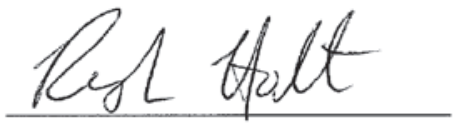

Rush Holt

Member of Congress 


\section{ommissioner Biographies}

\section{CHAIR OF THE COMMISSION ON LANGUAGE LEARNING}

Paul LeClerc was named Director of the Columbia Global Center-Paris, in the fall of 2012. His previous positions include President and CEO of the New York Public Library, President and CEO of Hunter College, Provost of Baruch College, Acting Vice Chancellor for Academic Affairs of the City University of New York (CUNY) system, and University Dean of Academic Affairs of CUNY. A scholar specializing in Voltaire and the French Enlightenment and former tenured Professor of French at Hunter, Baruch, and Union Colleges, he is the author, editor, or coeditor of five scholarly volumes. President Clinton named him to the President's Committee on the Arts and Humanities and he has been decorated by the governments of France and Spain. He currently serves as a Trustee of the J. Paul Getty Trust and Teachers College, Columbia University, and is a member of the Conseil Scientifique of the Bibliothèque nationale de France. He is a past Trustee of the Andrew W. Mellon Foundation, the Voltaire Foundation, the New York Public Library, the American Academy in Rome, the National Book Foundation, and other nonprofit organizations. He was elected a Fellow of the American Academy of Arts and Sciences in 2001.

\section{COMMISSION MEMBERS}

Martha G. Abbott is the Executive Director for the American Council on the Teaching of Foreign Languages (ACTFL). Her career began in Fairfax County Public Schools in Virginia, where she was a language teacher, a foreign language coordinator, and Director of High School Instruction. She has served on national committees to develop student standards, beginning teacher standards, and performance assessments in languages. She has held leadership positions at the national, regional, and state levels, and was named President of the ACTFL in 2003. She has been active as an advocate for language programs, serving as Cochair of the national public awareness campaign entitled 2005: The Year of Languages, and now heading up the ACTFL's Lead with Languages campaign, which will launch in 2017. She has received numerous awards recognizing her contributions to the language profession, including the Florence Steiner Award for Leadership and an American Classical League Merita Award. In 2016, she was appointed by President Obama to serve on the National Security Education Board.

Mark Aronoff is Distinguished Professor of Linguistics at Stony Brook University. He has also served as Associate and Deputy Provost at Stony Brook. He is the founding Chair of the Committee on Language in the schools of the Linguistic Society of America (LSA), a former Editor of Language, the Journal of the Linguistic Society of America, and a past President and current Fellow of the LSA. His recent research has included projects on the nature of morphological stems and roots, sign language, and stem ordering. He is also a member of a team currently studying Al-Sayyid Bedouin Sign Language. He has written or cowritten five books, including Contemporary Linguistics (2000) and What is Morphology? (2005), and has published over thirty scholarly papers. He is a Fellow of the American Association for the Advancement of Science, and was elected a Fellow of the American Academy of Arts and Sciences in 2013. 
Jessie "little doe" Baird is the Cofounder and volunteer Linguistic Director of the Wôpanâak Language Reclamation Project. She is also the Vice Chairwoman of the Mashpee Wampanoag Tribal Council and a member of the Wampanoag Women's Medicine Society. Trained as a linguist, she has written an introduction to the grammar of the Wôpanâak language, which she is working to turn into a complete grammar, and is creating a dictionary for the language. She is a former National Science Foundation Documenting Endangered Languages Fellow, a 2010 MacArthur Grant Fellow, and a member of the American Antiquarian Society. She has also served as a Commissioner on the Mashpee Housing Authority, a member of the Mashpee Wampanoag Indian Tribal Council Board of Directors, and a member of the Enrollment Committee for the tribe. She is currently the Linguist for Mukayuhsak Weekuw, a newly developed private immersion preschool for the Wôpanâak language.

David Chu is President of the Institute for Defense Analyses (IDA). IDA is a nonprofit corporation operating in the public interest. Its three federally funded research and development centers provide objective analyses of national security issues and related national challenges, particularly those requiring extraordinary scientific and technical expertise. He served in the Department of Defense as Under Secretary of Defense for Personnel and Readiness from 2001 to 2009 and as Assistant Secretary of Defense and Director for Program Analysis and Evaluation from 1981 to 1993 . From 1978 to 1981, he was the Assistant Director of the Congressional Budget Office for National Security and International Affairs. He served in the U.S. Army from 1968 to 1970. He was an Economist with the RAND Corporation from 1970 to 1978, Director of RAND's Washington Office from 1994 to 1998, and Vice President for its Army Research Division from 1998 to 2001. He is a member of the Defense Science Board and a Fellow of the National Academy of Public Administration. He is a recipient of the Department of Defense Medal for Distinguished Public Service with Gold Palm.

Dan E. Davidson is President and Cofounder of American Councils for International Education and Professor of Russian and Second Language Acquisition on the Myra T. Cooley Lectureship, at Bryn Mawr College. He has authored or edited over forty books and has written over sixty scholarly articles in the areas of language, culture, and language acquisition. He has previously served as Cochair for the Transformation of the Humanities and Social Sciences Initiative in Russia, sponsored by the Soros Foundations; Chair of the Alliance for International Exchange; President of the Joint National Committee for Languages, for which he serves as a member of the Executive Committee; and Vice President of the International Association of Teachers of Russian Language and Literature. He is currently the Cochair of the Working Groups on University-Based Innovation of the U.S.-Poland (PLUS-IP) and U.S.-Russia Bilateral Presidential Commissions on Innovation, and is immediate past Chair of the College Board World Languages Academic Advisory Committee. He is an elected foreign member of the Russian and Ukrainian Academies of Education. 
Nicholas B. Dirks is Chancellor of the University of California, Berkeley. He served as Executive Vice President and Dean of the Faculty at Columbia University, where, in addition to his work on behalf of undergraduate programs, he improved and diversified the faculty, putting special emphasis on interdisciplinary and international initiatives. He also served as Chair of the Anthropology Department at Columbia. Prior to his appointment at Columbia, he was Professor of History and Anthropology at the University of Michigan. He is the author of several books on South Asian history and culture and the impact of British colonial rule, including The Hollow Crown: Ethnohistory of an Indian Kingdom (1987), Castes of Mind (2007), and Scandal of Empire (2008). In 2015, he published a new volume of essays on a wide range of topics, entitled Autobiography of an Archive. His current projects concern the last years of British rule in India and the growing role of the United States in South Asia, as well as the global and technological environment for higher education in the century ahead. He was elected a Fellow of the American Academy of Arts and Sciences in 2014.

Brian T. Edwards is the Crown Professor in Middle East Studies and Professor of English, Comparative Literary Studies, and American Studies at Northwestern University. He is also the founding Director of Northwestern University's Program in Middle East and North African Studies, which offers an interdisciplinary undergraduate major, a Ph.D. certificate, and courses in Arabic, Hebrew, Persian, and Turkish languages. His interests lie in American culture and its global context, especially in the Middle East. His publications include two books, Morocco Bound: Disorienting America's Maghreb from Casablanca to the Marrakech Express (2005) and After the American Century: The Ends of U.S. Culture in the Middle East (2016); two edited collections, Globalizing American Studies (2010) and On the Ground: New Directions in Middle East and North African Studies (2013); and essays, articles, and op-eds in a range of both scholarly and mainstream publications, including Salon, Public Culture, Foreign Policy, Chicago Tribune, and The Chronicle of Higher Education. He was a Fulbright Fellow to Morocco and Fulbright Senior Scholar to both Egypt and Italy. He was named a 2005 Carnegie Scholar and was a 2008-2009 recipient of a New Directions Fellowship from the Andrew W. Mellon Foundation. In 2013, he was named an Emerging Leader by the Chicago Council on Global Affairs. In that capacity, he was lead author on a white paper published in 2015 by the Council entitled "Teaching Arabic in Our Schools: Globalizing Education for Chicago's Next Generation." He is Chair of the Chicago Arabic Teachers' Council, funded by a grant from the Qatar Foundation, which serves the more than 250 Arabic teachers in Chicagoland by building relationships between and providing resources to Arabic language instructors, school administrators, and education professionals. 
Karl Eikenberry is the Oksenberg-Rohlen Fellow and Director of the U.S.-Asia Security Initiative at Stanford University's Shorenstein Asia-Pacific Research Center. He previously served as the U.S. Ambassador to Afghanistan and had a thirty-five-year career in the U.S. Army, retiring with the rank of Lieutenant General. His military assignments included postings with operational units in the continental United States, Hawaii, Korea, Italy, and Afghanistan, the latter as the Commander of the American-led Coalition forces from 2005 to 2007 . He earned an Interpreter's Certificate in Mandarin Chinese from the British Foreign and Commonwealth Office while studying at the British Ministry of Defence Chinese Language School in Hong Kong. He is a board member of the Asia Foundation and council member of the International Institute for Strategic Studies. His essays on U.S. and international security issues have appeared in Foreign Affairs, Washington Quarterly, American Foreign Policy Interests, American Interest, The New York Times, The Washington Post, Foreign Policy, and Financial Times. He was elected a Fellow of the American Academy of Arts and Sciences in 2012 and is Codirector of the Academy project "Civil Wars, Violence, and International Responses."

Rosemary G. Feal has served as Executive Director of the Modern Language Association of America since 2002. She is General Editor of the Association's publishing and research programs and editor of two MLA publications. She also serves as an ex officio member of all committees and Commissions of the Association. She is on leave from her position as Professor of Spanish at the University at Buffalo, State University of New York, where she was Chair of the Department of Modern Languages and Literatures. From 1987 to 1998, she was a member of the faculty at the University of Rochester. A member and a past Vice President of the Board of Directors of the National Humanities Alliance, she also served on the Board of Directors of the American Council of Learned Societies. Coeditor of the SUNY Series in Latin American Iberian Thought and Culture, she is also Associate Editor of the Afro-Hispanic Review and former Senior Consulting Editor of the Latin American Literary Review. Her own publications include Isabel Allende Today; Painting on the Page: Interartistic Approaches to Modern Hispanic Texts (1995) and Novel Lives: The Fictional Autobiographies of Guillermo Cabrera Infante and Mario Vargas Llosa (1986). She was a 2011 to 2012 American Council on Education Fellow at the Five Colleges, Incorporated.

Carol Gluck is the George Sansom Professor of History at Columbia University. She specializes in modern Japan (from the late nineteenth century to the present), international relations, World War II, and history writing and public memory in Asia and the West. Her publications include Japan's Modern Myths (1985), Showa: The Japan of Hirohito (1992), Asia in Western and World History (coedited with Ainslee Embree, 1997), Words in Motion (coedited with Anna Tsing, 2009), Thinking with the Past: Japan and Modern History (2017), Past Obsessions: World War Two in History and Memory (forthcoming), as well as several books in Japanese, including Rekishi de kangaeru [Thinking with History] (2007) and Shisoshi toshite no gendai Nihon [Thought and Society 
in Contemporary Japan] (2016). She is the Chair of Columbia's Committee on Global Thought, Cochair of the Trustees Emeriti of the Asia Society, a member of the Board of Directors of the Japan Society, and a member of the American Philosophical Society. She was elected a Fellow of the American Academy of Arts and Sciences in 1991.

Nancy McEldowney was appointed as Director of the Foreign Service Institute in February 2013. In this role, she serves as the Chief Learning Officer for the U.S. Department of State and the U.S. government foreign affairs community. Previously, she served as President and Senior Vice President of the National Defense University. She has also served as Principal Deputy Assistant Secretary in the Department of State's Bureau of European and Eurasian Affairs and at the White House as Director of European Affairs on the National Security Council Staff. Overseas, she served as U.S. Ambassador to the Republic of Bulgaria and as Chargé and Deputy Chief of Mission in Turkey and Azerbaijan. She has been granted the State Department's Superior Honor Award on five occasions. She is also the recipient of the Sinclair Linguistic Award and of the Chairman of the Joint Chief's Joint Distinguished Civilian Service Award.

Philip Rubin is the Chief Executive Officer Emeritus and former Senior Scientist at Haskins Laboratories, where he currently serves as Senior Advisor to the President. Haskins is a private, nonprofit research institute affiliated with Yale University and the University of Connecticut that has a primary focus on the science of the spoken and written word, including speech, language, and reading. He is also an Adjunct Professor in the Department of Surgery, Otolaryngology, at the Yale University School of Medicine, a Research Affiliate in the Department of Psychology at Yale, and a Fellow at Yale's Trumbull College. He served as the Principal Assistant Director for Science in the Office of Science and Technology Policy in the Executive Office of the President of the United States, where he was also the Assistant Director for social, behavioral, and economic sciences, and led the White House neuroscience initiative. He has served as the Chair or Cochair of the National Academies Board on Behavioral, Cognitive, and Sensory Sciences, the National Science and Technology Council Committee on Science, the National Research Council Committee on Field Evaluation of Behavioral and Cognitive Sciences-Based Methods and Tools for Intelligence and Counter-Intelligence, and the Common Rule Modernization Working Group. He has been a member-at-large of the Executive Committee of the Federation of Associations in Behavioral \& Brain Sciences and Chairman of the Board of the Discovery Museum and Planetarium in Bridgeport, Connecticut. He is a Fellow of the American Association for the Advancement of Science, the Acoustical Society of America, the American Psychological Association, the Association for Psychological Science, and the Linguistic Society of America, a Senior Member of the Institute of Electrical and Electronics Engineers, and an elected member of the National Academy of Public Administration and the Psychonomic Society. 
Rubén G. Rumbaut is Distinguished Professor of Sociology at the University of California, Irvine, with research focusing on issues of international migration, refugees, and modes of immigrant incorporation. Since 1991, he has directed, with Alejandro Portes, the Children of Immigrants Longitudinal Study. In the 1980s, he studied the resettlement of Vietnamese, Laotian, and Cambodian refugees; in the 1990s, he directed the National Survey of Immigration Scholars in the United States; and in the 200os, he led the Immigration and Intergenerational Mobility in Metropolitan Los Angeles study. He has authored over two hundred scholarly articles, and coauthored or coedited eighteen books and special issues, including Legacies: The Story of the Immigrant Second Generation (2001), which won the Distinguished Book Award of the American Sociological Association as well as the Thomas and Znaniecki Award for best book in the immigration field. He is a Fellow of the National Academy of Education, and the recipient of the Distinguished Career Award from the American Sociological Association International Migration Section. He was elected a Fellow of the American Academy of Arts and Sciences in 2015.

Marta Tienda is the Maurice P. During '22 Professor of Demographic Studies and Professor of Sociology and Public Affairs at Princeton University. She is also the former Director of the Office of Population Research and past President of the Population Association of America. Her current research focuses on the lifecycle timing of migration and its effects on adolescent romantic relationships for emotional and physical well-being. She has authored over two hundred articles and book chapters about racial and ethnic inequality in the United States, international migration, access to higher education, and family structure differences. She served on the White House Commission on Educational Excellence for Hispanics and the Research Advisory Committee of the American Education Research Association. Currently she serves on the Board of the Population Reference Bureau, and is a Trustee of the Teachers Insurance Annuity Association, the Jacobs Foundation of Switzerland, and the Alfred P. Sloan Foundation. She is a member of the American Academy of Political and Social Sciences and the National Academy of Education, and is a former Guggenheim Fellow. She was elected a Fellow of the American Academy of Arts and Sciences in 1993.

Kenneth L. Wallach is Executive Chairman and former Chief Executive Officer (1998-2014) of Central National Gottesman, Inc., a privately owned global pulp and paper distribution company. He and his wife have been involved in philanthropic activities at the Radcliffe Institute for Advanced Study at Harvard University since its founding in 2000, as well as with various organizations in the New York City community. He serves as a Trustee and member of the Executive Committee of the American Museum of Natural History, as Director of the National Book Foundation (sponsor of the National Book Award) and Chair of its Investment Committee, and as Director and member of the Executive Committee of the 92nd St. Y, a nonprofit cultural and community center. He is also a member of the Council on Foreign Relations, the Harvard Committee on University Resources, and the Executive Committee for the Harvard University Capital Campaign. He was elected a Fellow of the American Academy of Arts and Sciences in 2007. 
Diane P. Wood is the Chief Judge of the U.S. Court of Appeals for the Seventh Circuit and a Senior Lecturer at the University of Chicago Law School. Prior to her judicial appointment in 1995, she was the Green Professor of International Legal Studies at the University of Chicago Law School, where she also served as Associate Dean from 1989 to 1992. From 1993 to 1995, she was Deputy Assistant Attorney General in the Antitrust Division of the U.S. Department of Justice. She clerked for Judge Irving L. Goldberg of the Fifth Circuit and for Justice Harry Blackmun of the United States Supreme Court. She currently sits on the Council of the American Law Institute and serves on the Board of the Constitutional Rights Foundation Chicago, an organization devoted to teaching elementary and secondary school students about the U.S. legal system. From 2007 to 2013, she served as a member of the Judicial Conference's Standing Committee on Rules of Practice and Procedure. She is a member of the Academy's Commission on the Humanities and Social Sciences. She was elected a Fellow of the American Academy of Arts and Sciences in 2004, and is Chair of the Council, Vice Chair of the Board, and an ex officio member of the Trust.

Pauline Yu became President of the American Council of Learned Societies in 2003, having served for ten years as Dean of Humanities at the University of California, Los Angeles. Her publications have focused on classical Chinese poetry, literary theory, comparative poetics, and issues in the humanities. She serves on the board of the American Academy of Arts and Sciences, the National Humanities Center, the Scholars' Council of the Library of Congress, the American Academy in Berlin, the Chiang Ching-kuo Foundation for International Scholarly Exchange, and the Henry Luce, Robert H. N. Ho Family, and Teagle Foundations, among others. She is a member of the American Philosophical Society and the Committee of 10o. She became a Fellow of the American Academy of Arts and Sciences in 1998. 


\section{AMERICAN ACADEMY OF ARTS \& SCIENCES Cherishing Knowledge, Shaping the Future}

Since its founding in 1780, the American Academy has served the nation as a champion of scholarship, civil dialogue, and useful knowledge.

As one of the nation's oldest learned societies and independent policy research centers, the Academy convenes leaders from the academic, business, and government sectors to examine the critical issues facing our global society.

Through studies, publications, and programs on Science, Engineering, and Technology; Global Security and International Affairs; the Humanities, Arts, and Education; and American Institutions and the Public Good, the Academy provides authoritative and nonpartisan policy advice to decision-makers in government, academia, and the private sector. 



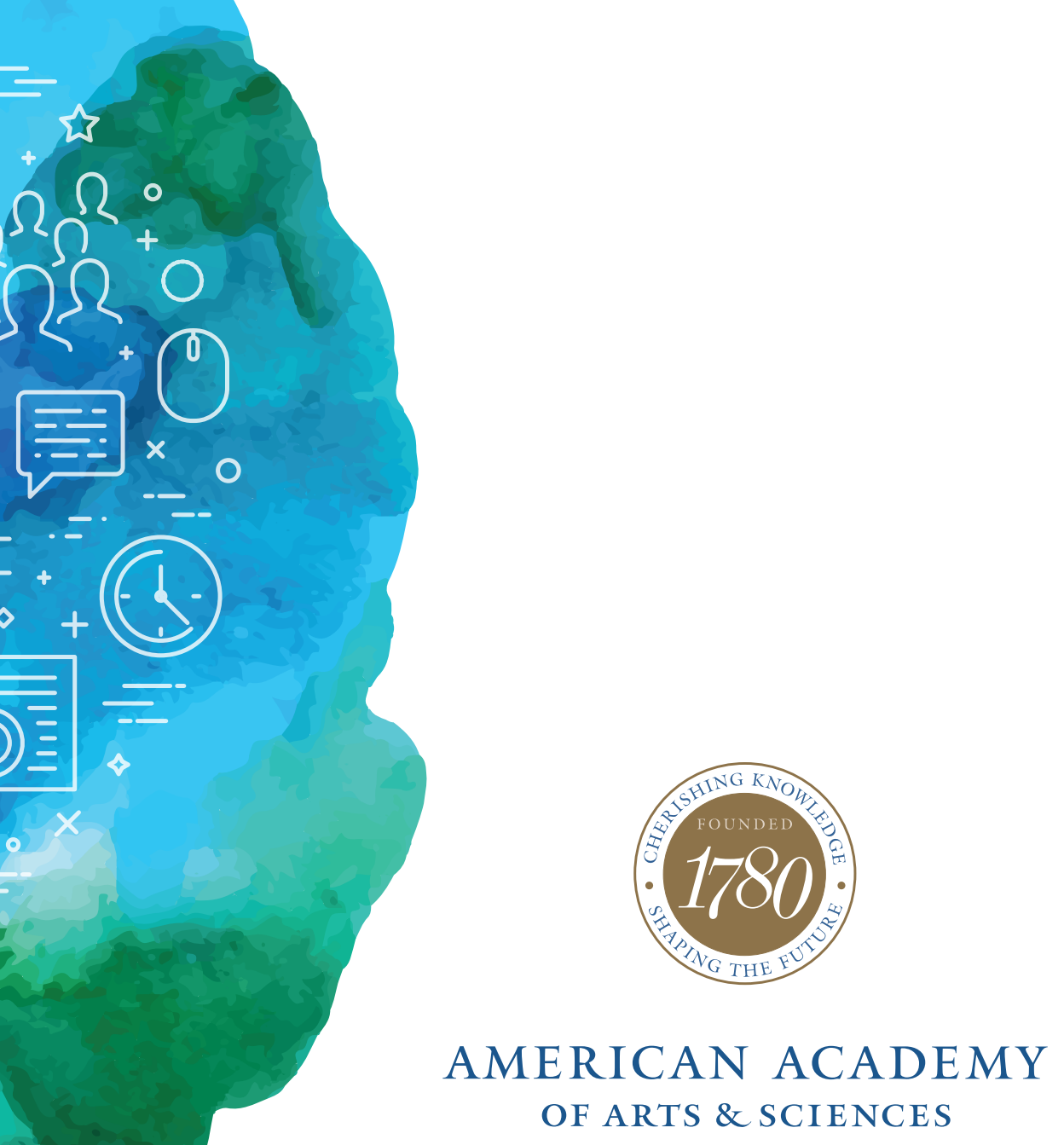

(9) @americanacad

www.amacad.org 